OPEN ACCESS

Edited by:

Sergueï O. Fetissov,

Université de Rouen, France

Reviewed by:

Sirish Chandra Bennuri, University of Arkansas for Medical

Sciences, United States

François Blachier,

Institut National de la Recherche

Agronomique (INRA), France

${ }^{*}$ Correspondence:

J. Bruce German

jbgerman@ucdavis.edu

Specialty section:

This article was submitted to

Clinical Nutrition

a section of the journal

Frontiers in Nutrition

Received: 28 February 2018

Accepted: 30 April 2018

Published: 18 May 2018

Citation:

Sanctuary MR, Kain JN, Angkustsiri K and German JB (2018) Dietary

Considerations in Autism Spectrum Disorders: The Potential Role of

Protein Digestion and Microbial

Putrefaction in the Gut-Brain Axis.

Front. Nutr. 5:40

doi: 10.3389/fnut.2018.00040

\section{Dietary Considerations in Autism Spectrum Disorders: The Potential Role of Protein Digestion and Microbial Putrefaction in the Gut-Brain Axis}

\author{
Megan R. Sanctuary ${ }^{1}$, Jennifer N. Kain ${ }^{2}$, Kathleen Angkustsiri ${ }^{3,4}$ and J. Bruce German ${ }^{5,6 *}$ \\ ${ }^{1}$ Department of Nutrition, University of California, Davis, Davis, CA, United States, ${ }^{2}$ Department of Neurobiology, Physiology \\ and Behavior Department, University of California, Davis, Davis, CA, United States, ${ }^{3}$ School of Medicine, Department of \\ Pediatrics, University of California, Davis, Sacramento, CA, United States, ${ }^{4}$ Department of Pediatrics, UC Davis MIND \\ Institute, Sacramento, CA, United States, ${ }^{5}$ Department of Food Science and Technology, University of California, Davis, \\ Davis, CA, United States, ${ }^{6}$ Foods for Health Institute, University of California, Davis, Davis, CA, United States
}

Children with autism spectrum disorders (ASD), characterized by a range of behavioral abnormalities and social deficits, display high incidence of gastrointestinal (GI) co-morbidities including chronic constipation and diarrhea. Research is now increasingly able to characterize the "fragile gut" in these children and understand the role that impairment of specific Gl functions plays in the Gl symptoms associated with ASD. This mechanistic understanding is extending to the interactions between diet and ASD, including food structure and protein digestive capacity in exacerbating autistic symptoms. Children with ASD and gut co-morbidities exhibit low digestive enzyme activity, impaired gut barrier integrity and the presence of antibodies specific for dietary proteins in the peripheral circulation. These findings support the hypothesis that entry of dietary peptides from the gut lumen into the vasculature are associated with an aberrant immune response. Furthermore, a subset of children with ASD exhibit high concentrations of metabolites originating from microbial activity on proteinaceous substrates. Taken together, the combination of specific protein intakes poor digestion, gut barrier integrity, microbiota composition and function all on a background of ASD represents a phenotypic pattern. A potential consequence of this pattern of conditions is that the fragile gut of some children with ASD is at risk for Gl symptoms that may be amenable to improvement with specific dietary changes. There is growing evidence that shows an association between gut dysfunction and dysbiosis and ASD symptoms. It is therefore urgent to perform more experimental and clinical research on the "fragile gut" in children with ASD in order to move toward advancements in clinical practice. Identifying those factors that are of clinical value will provide an evidence-based path to individual management and targeted solutions; from real time sensing to the design of diets with personalized protein source/processing, all to improve Gl function in children with ASD.

Keywords: microbiota, gastrointestinal, dietary protein, gut-brain, fragile gut, probiotics, constipation, diarrhea 


\section{INTRODUCTION}

Autism spectrum disorder (ASD) is characterized by varying degrees of neural dysfunction that lead to behavioral abnormalities including: stereotyped/repetitive behaviors, impairments in social interaction, lack of verbal and nonverbal language skills, insistence on routines and intense or idiosyncratic interests (1-3). ASD includes a heterogeneous range of disorders with various levels of intellectual functioning, verbal abilities, and multiple genetic etiologies. The estimated prevalence of autism in 8-year-olds in 2012 was 1:68 children with a much higher occurrence in boys $(23.6$ per 1,000$)$ than in girls $(5.3$ per 1,000$)(4)$. Over the past decade, the incidence rate has been steadily increasing (5). While increased awareness, concern and diagnostic criteria of ASD has expanded, some postulate that this increased prevalence cannot be entirely attributed to increased recognition and more expansive diagnostic criteria (5). There are currently no biomarkers for ASD and diagnosis is made solely on the history and observation of behavioral abnormalities using the Autism Diagnostic Interview - Revised (ADI-R) assessment (6) and the Autism Diagnostic Observational Schedule (ADOS) (7). Treatment of ASD symptoms focus on augmenting the obvious behavioral abnormalities with pharmacologic, cognitive, social, and communication therapies.

There is active research into the mechanisms that cause different autism phenotypes, including studies of genetic markers, structural, and functional brain abnormalities, immune dysfunction, gut microbial dysbiosis, sensitivity to environmental toxin exposure, and oxidative stress (8-13). However, gastrointestinal dysfunction is common in children with ASD (14) yet overlooked as unrelated to the disease process, or viewed as a disorder that simply co-occurs with the autistic symptoms. There is a strong correlation between the presence of gastrointestinal symptoms and autism severity (15) as ASD patients with gastrointestinal symptoms display higher measures of irritability, anxiety and social withdrawal (16). Gut dysfunction in children with ASD deserves further investigation, especially given the potential for intervention. Gut function is now recognized as highly variable, even within the normal population; many disease processes occurring at distant body sites have been found to have origins in gut, microbial composition and metabolism (17).

The concept of the "fragile gut" is proposed to be involved in a subset of children with ASD and that impaired gastrointestinal (GI) function, including deficiency in protein digestive capacity, is central to the GI symptoms associated with ASD and may exacerbate behavioral symptoms in ASD.

\section{Gastrointestinal and Immune Dysfunction in Children With ASD}

Gastrointestinal co-morbidities are common in children with ASD and have been reported to affect 9-91\% of patients (1821) with the prevalence of symptoms four times greater than in children without ASD (14). This unusually broad range is due to the variability in symptoms included in diagnosis as well as the limited number of studies assessing the prevalence of gastrointestinal symptoms. In addition, these symptoms are often underreported because many of these children are nonverbal or have difficulty with communication, and many parents have difficulty recognizing gastrointestinal symptoms in their children. Even so, the most commonly reported symptoms include chronic constipation, diarrhea, and abdominal pain (14, $20,21)$. Food allergies are also more common in children with ASD than age-matched controls (22) and may also be underdiagnosed due to the similar reasons (2). Certain foods appear to trigger both gastrointestinal and behavioral symptoms in children with ASD (18). To date, the poor reactions to particular foods experienced by these children has not been explicitly linked with differences in gut microbiota, immune function and digestive capacity in children with ASD relative to typically developing children.

Morphologically, there is evidence to suggest that gastrointestinal structure is altered in children with ASD. Examination of distal ileal biopsies from children with ASD reveals crypt cell proliferation, thickening of the basolateral membrane (23) of the gut epithelium and increased intestinal permeability $(24,25)$. These observations all suggest chronic immune activation in the gut and epithelial damage. One study found abnormally high intestinal permeability in nearly $40 \%$ of autistic patients and in $21 \%$ of their first-degree relatives whereas this excessive permeability was present in $<5 \%$ of normal control subjects $(24,25)$. Increased permeability would contribute to heightened reactions to food components in the intestinal tract of children with ASD. Interestingly, individuals with ASD on specific protein-restricted diets (wheat and dairy free) have significantly lower intestinal permeability than those on unrestricted diets (25). Children with ASD and gastrointestinal symptoms experience unique gastrointestinal immunopathology characterized by ileal nodular lymphoid hyperplasia (26), high levels of mucosal pro-inflammatory lymphocyte infiltration with inversely low levels of regulatory lymphocyte populations (27), and colonic lesions containing high numbers of infiltrating $\gamma \delta$ and $\mathrm{CD} 8^{+} \mathrm{T}$ cells with associated epithelial damage (23). Unlike inflammatory bowel diseases, there is lack of clear $\mathrm{T}_{\mathrm{H}} 1$ or $\mathrm{T}_{\mathrm{H}} 2$ skewing in ASD with the observation that IL-4, IL-2, and interferon gamma (IFN- $\gamma$ ) are elevated in the duodenal mucosa while IL-4 is elevated in the colon (27). Immune-mediated epithelial damage to the gut lining via serum IgG and complement $\mathrm{Clq}$ co-localization at the basolateral membrane (28) suggests that autoimmune mechanisms may play a role. Autoimmunity may arise out of increased immune responses to dietary proteins and potential cross reactivity to proteins in the gut or brain, which will be discussed in more detail in the following sections. Interestingly, children on specific protein-restricted diets show lower levels of activated colonic intraepithelial lymphocytes and underlying lamina propria lymphocytes $\left(\mathrm{CD}^{+} \mathrm{TNF} \alpha^{+}\right)$compared to children on unrestricted diets (27).

Immune abnormalities in ASD are not restricted to the gut and systemic immune imbalance is common. Changes in numbers and activation of macrophages, $\mathrm{T}$ cells, $\mathrm{B}$ cells, and natural killer cells have all been observed in patients with ASD $(29,30)$. While some studies have observed a shift from 
$\mathrm{T}_{\mathrm{H}} 1$ to $\mathrm{T}_{\mathrm{H}} 2$ cell type with decreased production of IL-2 and IFN- $\gamma$ and increased production of IL-4 (31), others state that there is no clear cytokine polarization profile, and attempting to categorize the disease based on the traditional $\mathrm{T}_{\mathrm{H}} 1 / \mathrm{T}_{\mathrm{H}} 2$ dichotomy may oversimplify and incorrectly characterize the immune dysfunction in children with ASD (32). Interestingly, in vitro stimulation of peripheral blood mononuclear cells from children with ASD with certain dietary proteins (including $\beta$-lactoglobulin and $\alpha$-lactalbumin from cow's milk and gliadin from wheat but not casein cow milk protein or soy protein) resulted in elevated pro-inflammatory cytokine production when compared to healthy controls as well as non-ASD controls with non-allergic food hypersensitivity $(33,34)$. Together, these observations suggest that overall gut immune function is altered and food antigens may provide a pro-inflammatory stimulus in children with ASD and gastrointestinal symptoms. However, it has been unclear whether these manifestations simply co-occur with the disorder, are a result of the abnormal neural functions that characterize the disorder, or are contributing to the etiology of the disease state.

\section{Characterization of the "Fragile Gut"}

Abnormal gastrointestinal functions in children with ASD include diminished digestive capacity. It is generally assumed that well-nourished, healthy children and adults who lack a history of gastrointestinal symptoms (e.g., chronic diarrhea, constipation, gastric reflux) or pancreatic insufficiency have little or no undigested or unabsorbed nutrients in the feces. The gastrointestinal tract digests and absorbs nutrients from consumed food matrices while excluding harmful bacteria and toxins. Pancreatic enzymes are produced in amounts that exceed substrate requirements allowing for complete digestion. Brush border enzymes and transporters have expression levels and activities capable of ensuring total absorption of nutrients in the small intestine (35). However, these normally successful processes may be disturbed in children with ASD and gastrointestinal symptoms.

The gut is the largest immune organ and the main site of immune system development (36). Considering that the gut immune system constantly encounters foreign material, immune imbalance can cause a lack of tolerance to dietary components and commensal microbes (37). The gastrointestinal tract is the second largest site of neurological tissue in the human body playing roles from nutrient sensing to appetite regulation (38).

For the purposes of this review a "healthy gut" is one that is able to (1) effectively extract and absorb nutrients from complex food matrices; (2) properly identify foreign materials as benign (e.g., common food substances) or harmful (e.g., pathogenic bacteria); (3) support the colonization of the gut by commensal organisms while eliminating pathogens; (4) restrict uptake or passage of potentially damaging substances out of the gut lumen through maintenance of gut barrier integrity; and (5) provide appropriate nutrient and energy status signals to other organ systems (35). All of these "healthy gut" functions are vital, and therefore, dysfunction of any one of these processes can cause or exacerbate disease throughout the body.
In this review, we will define the term "fragile gut" as a gastrointestinal tract that is basically "healthy" (i.e., lack of defined gastrointestinal disease), but is not robust to stressors, challenges, or microbial insults. Stressors include diets containing indigestible or toxic components or infectious agents. The concept is that a fragile gut influences a variety of clinical and non-clinical situations where gut dysfunction is not the explicit disease state or site, but rather a secondary problem. Examples of populations with a fragile gut include premature infants, the elderly, patients undergoing chemotherapy and children with ASD and gastrointestinal symptoms. The fragile gut phenotype in children with ASD includes a distribution of dysbiotic and pathological states. While a subset has been diagnosed as exhibiting explicit immunopathologies, others are asymptomic normally, but become symptomatic when confronted with challenges from poorly digested diets. Transient blooms of detrimental bacteria (e.g., proteobacteria) and "pulses" of microbial metabolites have been observed, as discussed below (Tables 1, 2). The causes of fragile gut remain incompletely understood. We hypothesize that the fragile gut's etiology results from a range of factors including digestive capacity, the digestibility of food ingredients consumed, genetic susceptibility as it affects gastrointestinal regulatory modulation, immune tolerance development, and gut microbial composition.

We propose that the fragile gut is influenced by dietary protein digestion. Incomplete digestion increases microbial protein fermentation (putrefaction) and inflammatory putrefactive metabolites, which can result in decreased gut barrier integrity, increased gut-associated immune responses, and microbial population shifts. In some children with ASD, reduced proteolytic capacity and colonic putrefaction may cause gastrointestinal problems and also exacerbate ASD symptoms (Figure 1). Identification of a fragile gut phenotype in ASD has both diagnostic and therapeutic applications. Identification of susceptibility and characterization of exogenous triggers has diagnostic implications. Therapeutic implications include avoidance of specific triggers and enhancement of the "robustness" of the intestinal microbiota, immune system, and intestinal tissues.

It is important to note that most of the available evidence linking gut dysfunction and dysbiosis to ASD is at this point based on associations and not causal relationships. Therefore, we are calling for future experimental and clinical studies designed to specifically address the potential causal relationship between these factors, including the gold standard of dietary intervention trials in children with ASD and GI symptoms.

\section{EVIDENCE FOR PROTEIN MALDIGESTION IN CHILDREN WITH ASD \\ Low Digestive Enzyme Activity}

Protein digestive capacity may be impaired in some children with ASD, which would contribute to the abnormal immune activation and gastrointestinal symptoms observed in these populations (Figure 1). However, there are no studies directly assessing the level and activity of proteolytic digestive enzymes 
TABLE 1 | Overview of studies exploring the gut microbiota in children with ASDs.

\begin{tabular}{|c|c|c|c|c|c|c|}
\hline Comparison & Sample site & Method & Level & Type & Change & References \\
\hline $\begin{array}{l}\text { ASD }(n=15) \\
\text { vs. TD }(n=8)\end{array}$ & Stool & $\begin{array}{l}\text { 16S rRNA } \\
\text { primers } \\
\text { RT-PCR }\end{array}$ & Genus, species & $\begin{array}{l}\text { Clostridium bolteae }(\mathrm{s}) \\
\text { Cluster I }(\sim \mathrm{g}) \\
\text { Cluster XI }(\sim \mathrm{g})\end{array}$ & $\begin{array}{l}\uparrow \\
\uparrow \\
\uparrow\end{array}$ & (40) \\
\hline $\begin{array}{l}\text { ASD }+ \text { GI }(n \\
=33) \text { vs. SIB } \\
(n=7) \text { vs. TD } \\
(n=8)\end{array}$ & Stool & $\begin{array}{l}454 \text { Titanium } \\
\text { pyrosequencing } \\
\text { (culture-ind) }\end{array}$ & $\begin{array}{l}\text { Phylum, genus, } \\
\text { species }\end{array}$ & $\begin{array}{l}\text { Firmicutes }(\mathrm{p}) \\
\text { Actinobacteria }(\mathrm{p}) \\
\text { Bacteroidetes }(\mathrm{p}) \\
\text { Proteobacteria }(\mathrm{p}) \\
\text { Bifidobacterium angulatum }(\mathrm{s}) \\
\text { Bifidobacterium longum }(\mathrm{s}) \\
\text { Bifidobacterium }(\mathrm{g}) \\
\text { Bacteroides }(\mathrm{g}) \\
\text { Clostridium }(\mathrm{g}) \\
\text { Desulfovibrio }(\mathrm{g}) \\
\text { Ruminococcus }(\mathrm{g}) \\
\text { Desulfovibrio piger }(\mathrm{s}), \mathrm{D} \text {. desulfuricans }(\mathrm{s}), \text { D. intestinalis } \\
\text { (s) } \\
\text { Bacteroides vulgates }(\mathrm{s}) \\
\text { Overall diversity and richness }\end{array}$ & $\begin{array}{l}\downarrow \\
\downarrow \\
\uparrow \\
\uparrow \\
\downarrow \\
\downarrow \\
\downarrow \\
\uparrow \\
\uparrow \\
\uparrow \\
\downarrow \\
\uparrow \\
\uparrow \\
\uparrow\end{array}$ & (42) \\
\hline $\begin{array}{l}\text { ASD }(n=58) \\
\text { vs. TD }(n= \\
\text { 39) }\end{array}$ & Stool & Culture? & Genus, species & $\begin{array}{l}\text { Bifidobacterium }(\mathrm{g}) \\
\text { Enterococcus }(\mathrm{g}) \\
\text { Lactobacillus }(\mathrm{g}) \\
\text { Bacillus }(\mathrm{g}) \\
\text { Klebsiella oxytoca }(\mathrm{s})\end{array}$ & $\begin{array}{l}\downarrow \\
\downarrow \\
\uparrow \\
\uparrow\end{array}$ & (15) \\
\hline $\begin{array}{l}\text { ASD }(n=23) \\
\text { vs. SIB }(n= \\
\text { 22) vs. TD }(n \\
=9)\end{array}$ & Stool & $\begin{array}{l}16 S \text { rRNA } \\
\text { primers } \\
\text { RT-PCR }\end{array}$ & Genus, species & $\begin{array}{l}\text { Bifidobacteria spp (vs. CON and SIB) } \\
\text { Akkermansia muciniphila (vs. CON) } \\
\text { Bacteroides fragilis (ASD: +GI vs. -Gl) }\end{array}$ & $\begin{array}{l}\downarrow \\
\downarrow \\
\uparrow\end{array}$ & (21) \\
\hline $\begin{array}{l}\text { ASD vs. TD }(n \\
=20)\end{array}$ & & $\begin{array}{l}454 \text { Titanium } \\
\text { pyrosequencing }\end{array}$ & Phylum, genus & $\begin{array}{l}\text { Proteobacteria }(p) \\
\text { Verrucomicrobia }(p) \\
\text { Akkermansia }(g) \\
\text { Prevotella }(g) \\
\text { Veillonellaceae }(f) \\
\text { Overall diversity }\end{array}$ & $\begin{array}{l}\downarrow \\
\downarrow \\
\uparrow \\
\downarrow \\
\downarrow \\
\downarrow\end{array}$ & (44) \\
\hline $\begin{array}{l}\text { ASD vs. PDD } \\
\text { vs. TD }(n= \\
10)\end{array}$ & Stool & $\begin{array}{l}16 S \text { rDNA and } \\
\text { rRNA primers } \\
\text { RT-PCR }\end{array}$ & All levels & $\begin{array}{l}\text { Overall diversity } \\
\text { Firmicutes (rRNA and rDNA) (p) } \\
\text { Bacteroidetes }(\mathrm{p}) \\
\text { Fusobacteria and Verrucomicrobia }(\mathrm{p}) \\
\text { Differential rRNA clustering (not rDNA) } \\
\text { Ruminococcaceae }(\mathrm{f}) \\
\text { Faecalibacterium/Ruminococcus }(\mathrm{g}) \\
\text { Clostridiaceae }(\mathrm{f}) \\
\text { Lachnospiraceae }(\mathrm{f}) \\
\text { Prevotella and Alistipes }(\mathrm{g}) \\
\text { Sutterellaceae }(\mathrm{f}) \\
\text { Parasutterella }(\mathrm{g}) \\
\text { Enterobacteriaceae }(\mathrm{f}) \\
\text { Proteus and Shigella }(\mathrm{g}) \\
\text { Bifidobacteria }(\mathrm{g}) \\
\text { Akkermansia muciniphila }(\mathrm{s})\end{array}$ & $\begin{array}{l}\uparrow \\
\downarrow \\
\uparrow \\
\downarrow \\
\downarrow \\
\uparrow \\
\uparrow \\
\uparrow \\
\uparrow \\
\uparrow \\
\downarrow \\
\uparrow\end{array}$ & (45) \\
\hline
\end{tabular}

ASD, autism spectrum disorder; TD, typically developing; +GI, with Gl symptoms; -GI, without Gl symptoms; SIB, sibling of ASD; PDD, pervasive developmental disorder; p, phylum; c, class; o, order; f, family; g, genus; s, species. 
TABLE 2 | Overview of studies exploring gut putrefactive metabolites in children with ASDs.

\begin{tabular}{|c|c|c|c|c|c|}
\hline Comparison & Sample site & Metabolites & Change & $\begin{array}{l}\text { Microbiota assoc/other } \\
\text { comments }\end{array}$ & References \\
\hline $\begin{array}{l}\text { Infants }(n=28) \\
\text { children }(n=60) \\
\text { and ASD }(n=262)\end{array}$ & Urine & $\begin{array}{l}\text { HPHPA } \\
\text { 3-(3-hydroxyphenyl)-3-hydroxy- propionic acid } \\
\text { (Phe metabolite) }\end{array}$ & $\uparrow \uparrow$ & $\begin{array}{l}\text { Clostridia spp (some) hyp } \\
\text { Psychosis and level } \downarrow \text { w antibiotic } \\
\text { treatment in schizophrenia }\end{array}$ & $(46)$ \\
\hline $\begin{array}{l}\text { ASD }(n=59) \text { vs. TD } \\
(n=59)\end{array}$ & Urine & $\begin{array}{l}\text { p-cresol } \\
\text { Only age }<7 \text { and corr with autism severity }\end{array}$ & $\uparrow$ & $\begin{array}{l}\text { Clostridium difficile (s) hyp } \\
\text { Expresses p-hydroxyphenylacetate } \\
\text { decarboxylase }\end{array}$ & $(47)$ \\
\hline Case report & Blood/urine & $\begin{array}{l}\text { Propionic acid } \\
\text { Ammonia }\end{array}$ & $\begin{array}{l}\uparrow \\
\uparrow\end{array}$ & Associated with pancreatitis & $(48)$ \\
\hline $\begin{array}{l}\operatorname{ASD}(n=23) \text { vs. TD } \\
(n=31,22 \mathrm{SIB})\end{array}$ & Stool & $\begin{array}{l}\text { Ammonia } \\
\text { Phenol } \\
\text { Acetate, butyrate, propionate } \\
\text { Isobutyrate, valerate, isovalerate } \\
\text { p-cresol }\end{array}$ & $\begin{array}{l}\uparrow \\
\uparrow \\
\uparrow \\
\uparrow \\
-\end{array}$ & Similar dietary intakes & $(49)$ \\
\hline $\begin{array}{l}\text { ASD vs. PDD vs. TD } \\
(n=10)\end{array}$ & Stool & $\begin{array}{l}\text { Free amino acids (FAA) } \\
\text { Ammonia } \\
\text { Phenol } \\
\text { p-cresol } \\
\text { Propionic acid } \\
\text { Indole/3-methylindole } \\
\text { Total med and short chain fatty acids }\end{array}$ & $\begin{array}{l}\uparrow \\
\uparrow \\
\uparrow \\
\uparrow \\
\uparrow \\
\uparrow \\
\downarrow\end{array}$ & $\begin{array}{l}\uparrow \text { Bacteroides (g) corr } \\
\uparrow \text { Bacteroides (g) corr } \\
\uparrow \text { Clostridia (g) hyp } \\
\uparrow \text { Clostridia (g) hyp } \\
\uparrow \text { Bacteroides (g) corr } \\
\uparrow \text { Clostridia (g) corr } \\
\downarrow \text { Ruminococcoceae (f) hyp }\end{array}$ & $(45)$ \\
\hline $\begin{array}{l}\operatorname{ASD}(n=33) \text { vs. TD } \\
(n=33)\end{array}$ & Urine & $\begin{array}{l}\text { Total p-cresol and derivatives } \\
\text { p-cresylsulfate } \\
\text { p-cresylglucuronate } \\
\text { Free p-cresol }\end{array}$ & $\begin{array}{l}\uparrow \\
\uparrow \\
\uparrow \\
-\end{array}$ & Exclusive to age $<8$ for all & $(50)$ \\
\hline
\end{tabular}

ASD, autism spectrum disorder; TD, typically developing; SIB; sibling of ASD; corr, correlation found; hyp, hypothesis only.

in these children. One study found that the activity of several saccharolytic digestive enzymes is low in children with ASD and gastrointestinal symptoms (51). Characterization of the upper gastrointestinal tract in these children revealed decreased activity of one or more disaccharidases or glucoamylase in $58.3 \%$ of children with ASD compared to healthy controls. Remarkably, nearly half of these children showed decreased activity in two or more of these enzymes and all children with low enzyme activity had loose stools and/or gaseousness. Stimulation of pancreatic output with secretin administration showed that children with ASD on average had a higher pancreatico-biliary fluid output compared to healthy controls (51). While secretin treatment is now a disproven therapy (52), the authors hypothesized that the hypersecretory response to intravenous secretin might be due to the absence of regular secretin stimulation of the pancreas. However, this response could also be due to chronic pancreatic insufficiency as increased pancreatico-biliary output has been observed in patients with exocrine pancreatic insufficiency (53). While this study found no evidence of pancreatic insufficiency in children with ASD, they did observe hypertrophy and hyperplasia of the upper gastrointestinal Paneth's cells (specialized immune cells interdigitated between enterocytes of the intestinal epithelium). The authors noted that Paneth cell hypertrophy/hyperplasia has also been reported in hamsters after ligation of the pancreatic duct (54) and in patients with chronic pancreatitis (55).

Later studies investigated brush border enzyme function in children with ASD further. One study found significantly decreased levels of ileal sucrose isomaltase, maltase glucoamylase, and lactase mRNA in children with ASD and gastrointestinal symptoms when compared to typically developing children who also had similar gastrointestinal symptoms (43); therefore, these findings are autism-specific and not generalized to all gastrointestinal dysfunction. Indeed, $93.3 \%$ of children with autism in this study had a deficiency in at least one of these enzymes, while $80 \%$ had deficiencies in at least two, and $73.3 \%$ had deficiencies in all three (with deficiency defined as levels $<25 \%$ of controls). These digestive enzymes are located on the brush border of the enterocyte membrane, and thus their levels and activity could be decreased by chronic inflammation of the gastrointestinal tract or other disturbances in enterocyte maturation and migration. If this is the case, then other brush border enzymes, such as peptidases, are impaired as well.

\section{Altered Levels of Systemic Amino Acids and Peptides}

Children with ASD who have shown elevated levels of urinary peptides of dietary origin (56) provide further evidence that this population experiences impaired protein digestion coupled with increased intestinal permeability. Unfortunately, the interpretation of these findings must be viewed with some caution as they have arisen out of the "opioid excess theory." This theory of ASD's origin hypothesizes that breakdown products of certain dietary proteins (mainly casein and gluten) are potent agonists of opioid receptors that can exert systemic effects and are able to cross the blood brain barrier (56). Indeed, many of the urinary peptides detected from children with ASD can be classified as exorphins (exogenous opioids) 
and include casomorphins, gliadinomorphins, gluteomorphins, deltorphin and dermorphin. Treatment of these subjects with an extended gluten-free, casein-free (GFCF) diet ( $2-4$ years) resulted in significant reduction in urinary peptide levels as well as improvement in behavioral metrics (57-59), despite abundant intake of meat and fish protein (58). Suggestively, several animal studies have shown that inhibition of gut peptidases, specifically dipeptidyl peptidase IV (DPP-IV), results in increased levels of urinary peptides of dietary origin $(60,61)$. While the "opioid excess theory" is not widely accepted and supporting evidence is limited, these findings support the hypothesis that a subset of children with ASD experience reduced digestive enzyme activity, and undigested dietary peptides can cross the intestinal mucosal barrier and exert biological effects systemically.

Plasma amino acid profiles tend to be altered in children with ASD, although studies have reported mixed results. While some studies have shown elevated levels of certain plasma amino acids, such as glutamic acid, aspartic acid $(62,63)$ and taurine (62), others have shown decreased levels of certain amino acids, especially glutamine (62-64). Arnold et al. (65) found that children with ASD on both restricted (GFCF) and unrestricted diets had frequent essential amino acid deficiencies. Compared to controls, children with autism on unrestricted diets were more likely to be deficient in valine, leucine, phenylalanine, and lysine, while children on restricted diets were additionally more likely to be deficient in isoleucine (65). Adams et al. found decreased levels of isoleucine, phenylalanine, tryptophan, and taurine; they hypothesize that this is due to decreased protein intake or impaired protein digestion. They postulated that the latter hypothesis is more likely because most essential amino acid levels were normal (66). Low levels of certain plasma amino acids in children with ASD suggest both an impaired capacity for protein digestion as well as increased passage of dietary peptides into systemic circulation by way of compromised intestinal integrity. Finally, certain plasma amino acids either serve as neurotransmitters (e.g., glutamate) or serve as precursors (e.g., tryptophan and tyrosine) for important neurotransmitters (e.g., serotonin and dopamine). Perturbations in these systems are common in children with autism and contribute significantly to autistic symptoms (67-69).

\section{Autoantibodies Against Dietary Peptides and Gut Peptidases}

Low proteolytic enzyme activity in the gut would lead to increased levels of undigested peptides in the gut lumen, resulting in increased plasma and urinary concentrations of these peptides. High levels of foreign peptides in the systemic circulation can induce an adaptive immune response that leads to autoantibody (i.e., self-reactive antibody) production (Figure 1). Therefore, the subsequent cross-reaction of the resulting antibodies with neural tissue proteins may play a role in the etiology of autistic symptoms.

Multiple studies have found elevated levels of circulating antibodies against several microbial products including Chlamydia pneumoniae peptide Streptococcus M protein (70), streptokinase (SK) (71), and heat shock protein (HSP-60) (72) in children with ASD compared to healthy controls. Elevated levels of antibodies against dietary proteins have also been detected in children with autism including IgG, IgM and IgA against butyrophilin milk protein (70), casein (57, 71, 73-75), gliadin (57, 71, 72, 74, 75), IgG against deamidated $\alpha$-gliadin (75), and $\operatorname{IgA}$ against lactalbumin, $\beta$-lactoglobulin and ovalbumin (73).

Bacterial proteins and peptides have been reported to show sequence homology and subsequently induce antibody crossreactivity with certain human brain tissue proteins (74). Immune reactions mounted against dietary peptides may subsequently damage neural tissue in children with ASD that cause or exacerbate behavioral symptoms. Elevated levels of antibodies were found against myelin basic protein and neurofilament proteins in $58-70 \%$ of children with ASD $(76,77)$ with studies corroborating these findings and discovering elevated levels of antibodies against a number of other neuronal proteins including myelin-associated glycoprotein, ganglioside, myelin oligodendrocyte glycoprotein (70), and cerebellar peptides (74). In vitro studies have also demonstrated that antibodies against proteins of gut origin are able to cross-react with neuronal proteins and peptides (74). One study showed that antibodies against the gliadin peptide cross-reacted with cerebellar peptide with $17 \%$ binding (74). Antibodies against crude (undigested) gliadin showed $23 \%$ binding to cerebellar peptide, milk protein showed 56\%, egg protein showed $68 \%$ binding, while corn or soy protein showed little to no crossreactivity. Additionally, significant increases in anti-cerebellar peptide antibodies were concomitant with increases in antigliadin antibodies in most ASD sera, thus supporting the hypothesis of an autoimmune etiology. Furthermore, studies of the maternal origins of autoantibodies in ASD found that fetal brain protein reactive immunoglobulins can be isolated from approximately $12 \%$ of mothers who have children with ASD (78). Subsequent studies using a nonhuman primate model showed that the administration of these autoantibodies to rhesus monkeys during pregnancy resulted in offspring with abnormal social behavior and enlarged brain volume compared to controls (79). This group has since defined an autism subset, termed maternal autoantibodyrelated (MAR) autism, defined by the maternal presence of clinically significant ASD-specific antibody biomarkers (80). Children found to fall into the MAR-autism subset experience elevated stereotypical behaviors (80) and more extreme brain enlargement (81) compared to children with other types of autism.

Autoimmune cross-reactivity has also been shown to affect several gastrointestinal proteins in addition to neural proteins. Vojdani et al. hypothesized that antibodies against antigens from infectious agents may react with lymphocyte receptors $(71,74)$. Two of these lymphocyte receptors, DPP-IV and aminopeptidase $\mathrm{N}$ (CD13), are also located on the brush border of the small intestine and are involved in degradation of small peptides as part of the protein digestive process. They found that ASD sera contained significantly greater levels of antibodies against both of these gut peptidases compared to healthy children. In addition, the vast majority of children with 

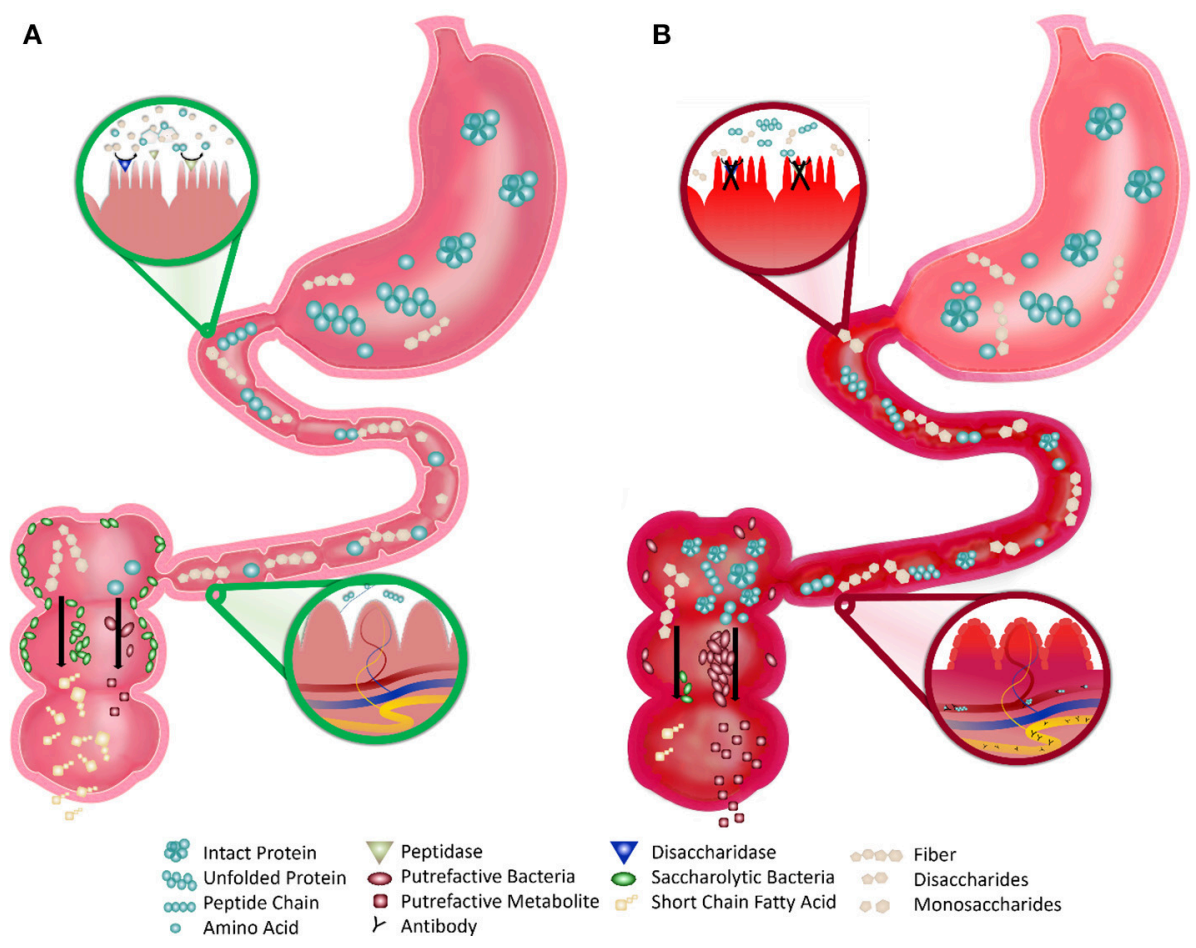

FIGURE 1 | Robust vs. Fragile Gut Function in Children with ASD. (A) Robust Gut: the healthy gut displays robust digestion of proteins and simple sugars by the small intestine brush border enzymes that make these nutrients absorbable. After digestion, very few intact nutrients remain and indigestible polysaccharides (fiber) remain. This fiber is consumed by saccharolytic bacteria, which line most of the large intestine, and produce beneficial byproducts (such as short chain fatty acids). Undigested proteins or amino acids are consumed by putrefactive bacteria, which are few in number, and produce potentially harmful putrefactive metabolites that are easily detoxified. The blood and lymphatics in the villi do not directly interact with the lumen of the small intestine, preventing the interaction of antigenic food molecules with the underlying immune tissue. (B) Fragile Gut: the fragile gut of children with autism displays reduced digestive capacity. The inflammation and deterioration of the gut lining may cause reduced expression and activity of brush border disaccharidases and peptidases and greater amounts of intact simple sugars and proteinaceous substrates and less fermentable fiber. This proteinaceous substrate is consumed by the more prevalent putrefactive bacteria producing greater amounts of putrefactive metabolites, such as ammonia, phenols, and sulfides. The blood and lymphatics in the villi are in contact with the lumen due to the excessive inflammation and the undigested proteins in the intestine are able to directly pass. This process allows for interaction of antigenic proteins with immune tissue leading to an aberrant immune response and subsequent autoantibody production.

ASD who had elevated levels of these anti-peptidase antibodies also had elevated levels of antibodies against gliadin, casein, SK, or HSP-60 and many had elevated levels of all of these antibodies $(71,72)$. In vitro studies found that binding of antiDPP-IV antibodies to DPP-IV significantly reduced its activity $(p<0.05)$ (72). These findings suggest that children with ASD have elevated levels of antibodies against gut peptidases that may impair their function and lead to increased levels of peptides in the gut. This would increase the likelihood that dietary peptides enter systemic circulation and set off an autoimmune reaction that leads to neuronal protein targeting in the brain.

\section{Intestinal Microbial Dysbiosis}

Some of the microbial perturbations reported in ASD (Table 1) support the hypothesis of impaired protein digestion in this cohort. Impaired protein digestion would not only result in increased levels of peptides entering the systemic circulation, but also entering the distal gastrointestinal tract. This increased level of proteinaceous substrate could modulate the composition of the microbiota and lead to dysbiosis, an imbalance between protective and detrimental taxa in the gut (Figure 1). While studies on protein fermentation (putrefaction) in the human colon are extremely limited, several studies indicate that increased levels of protein in the colon leads to increased levels of protein-metabolizing (putrefactive) bacteria $(82,83)$, reduced levels of fiber-fermenting (saccharolytic) bacteria (83-85), and reduced bacterial diversity (85) as well as increased levels of putrefactive metabolites in the colon $(83,85-88)$. These metabolites have been associated with inflammatory bowel diseases such as ulcerative colitis $(89,90)$. The effects of these metabolites on host physiology have been studied using mainly in vitro models and have been shown to increase intestinal permeability (87, 91-93) and reduce overall health of colonocytes (87, 91, 94-96). Therefore, the prevalence of gastrointestinal symptoms may be directly related to an altered gut microbiota in these children.

Table 1 lists the studies examining the fecal microbiome of children with ASD. Children with ASD appear to have 
more bacterial diversity $(42,45)$ and possess lower overall abundance of potentially beneficial taxa, such as Bifidobacteria and Akkermansia, even among healthy siblings relative to unrelated control children $(15,21,42)$, though some populations appear to differ from this trend $(42,44)$. Further, reports typically show that children with ASD have higher counts of clostridia than controls (39-43), though this is not universally true (44). Interestingly, certain species of clostridia are very adept at metabolizing protein and amino acids (97-99). Studies examining bacterial enrichment in batch incubations of human fecal slurries supplemented with peptides and amino acids have found an outgrowth of certain species of clostridia (97, 99). The majority of the proteolytic activity in the large intestine is attributed to bacterial taxa including Bacteroides, Clostridium, Propionibacterium, Fusobacterium, Streptococcus, and Lactobacillus (98). Both Bacteroides (21, 42) and Lactobacillus (15) have been found at higher levels in children with ASD. In addition, rats fed a high protein diet have been shown to have increased levels of Bacteroides spp. and certain Proteobacteria, including escherichia/shigella, as well as decreased levels of akkermansia and bifidobacteria spp. relative to rats on normal protein diet (83). Proteobacteria have also been shown to be increased in children with ASD $(42,43)$. These results suggest that proteolytic bacterial taxa are enriched in children with ASD as a consequence of high levels of undigested protein entering the colon. However, studies in this area are limited, and data on the effects of high protein diets on the colonic microbiota in humans are scarce. In addition, the activities of these gut bacteria remain to be determined and future studies will be needed to define the metabolic activities (e.g., metagenomics and metatranscriptomics) of the gut microbiota rather than purely microbial composition.

From a symptomatic perspective, gastrointestinal complaints were significantly associated with Clostridia in patients with ASD when compared with healthy unrelated controls (41). In addition to differences in Bifidobacterium spp., Wang et al., also found the abundance of Akkermansia muciniphila (A. muciniphilia) to be decreased in ASD, and again intermediate in siblings, as well as elevated relative numbers of " $B$. fragilis" in children with ASD and gastrointestinal symptoms vs. children with ASD without gastrointestinal symptoms. It was hypothesized that lower levels of A. muciniphila indicate a thinner gastrointestinal mucus barrier, since this species is mucolytic and may be reduced due to lack of substrate (21). Williams et al. (43) compared the bacterial adherent to the intestinal mucoepithelium (from biopsies) in children with ASD and gastrointestinal co-morbidities to children with gastrointestinal issues but without ASD. Comorbid conditions were also similar between groups with the most commonly reported conditions being atopic manifestations (asthma, atopic dermatitis, and allergic rhinitis). Bacteroidetes and Firmicutes were the most prevalent taxa in ileal and cecal biopsies of both autistic and control children. However, there was a significant increase in Firmicutes/Bacteroidetes ratios in autistic ileal and cecal samples, which has been interpreted to reflect a general state of dysbiosis in other conditions, such as obesity (100).
Overall, these studies support the hypothesis that abnormal microbial composition of the gastrointestinal tract can cause or exacerbate GI symptoms associated with ASD. Other studies suggest that this abnormal microbiota may even be associated with the symptoms and severity of ASD (15). While dietary components are the primary determinants of gut microbial composition after birth in mammals, the cause of the dysbiosis observed in ASD has not been thoroughly studied in the context of diet, protein maldigestion, or gut abnormalities. However, the combined effects of immune imbalance with digestive dysfunction and intake of dietary proteins with low digestibility may all play a role in promoting gastrointestinal symptoms and microbial dysbiosis in this susceptible population. Furthermore, these dysbiotic bacteria may directly cause or exacerbate gastrointestinal symptoms due to their potential to produce damaging metabolic byproducts.

\section{High Levels of Fecal Putrefactive Metabolites}

A variety of enteric bacteria, including clostridia, desulfovibrio, and Bacteroidetes are enriched in batch cultures high in proteinaceous substrates (97-99) and in children with ASD $(39,42)$. These bacteria can ferment dietary proteins in a process called putrefaction $(98,101)$. Byproducts of microbial putrefaction can be detrimental to gut health (102). Microbial metabolites produced from the saccharolytic fermentation of dietary fiber (e.g., vitamins and short chain fatty acids) are generally recognized as being beneficial to human health. In contrast, the products of putrefaction [e.g., ammonia, phenols, indoles, sulfides and biogenic amines (101)] have been associated with reduced viability of colonic epithelial cells in vitro (103), increased intestinal permeability (92, 93), DNA damage (104) and the inhibition of cellular respiration in colonocytes $(95,105,106)$. Increased colonic protein, due to reduced digestive capacity, serves as a food source for these putrefactive colonic microbes. Thus, a diminished capacity to digest dietary protein in the small intestine and/or consumption of proteins resistant to digestion can lead to elevated colonic protein and peptide levels, and thus increased concentrations of these detrimental protein-derived metabolites. The heightened level of putrefactive metabolites found in children with ASD (Table 2) $(47,49,63,107,108)$ suggests that protein maldigestion in the small intestine plays a role in driving not only gastrointestinal symptoms, but also neural symptoms of this disorder.

One specific consequence of protein fermentation is the ability of certain gut bacterial species to catabolize threonine and alanine to produce propionic acid, a metabolite that also increases with increased protein in the diet (101). Propionic acid concentrations are higher in children with ASD than healthy children (49). In addition, acute and chronic abnormalities of brain function are well-documented in propionic acidemia, a common form of organic aciduria resulting from an inborn error of metabolism that causes propionyl-CoA carboxylase deficiency $(109,110)$. One case study reported the occurrence of autism in a 7-year old girl with propionic acidemia (48). While it is 
possible that these disorders co-occurred by coincidence, the authors postulate that the propionic acidemia contributed to the emergence of ASD symptoms. MacFabe and colleagues have thus eloquently hypothesized that proprionic acid plays a role in the etiology of ASD (107) and have subsequently developed an animal model of ASD using proprionic acid to induce autisticlike symptoms (111). Rats treated intracerebroventricularly with propionic acid displayed numerous behavioral and physiological traits characteristic of human ASD including hyperactivity, repetitive and abnormal motor movements, seizures, increased brain oxidative stress markers (lipid peroxidation products and protein carbonylates), decreased glutathione and glutathione peroxidase activity, and increased neuro-inflammation indicated by increased reactive astrogliosis and activated microglia. Subsequent studies showed that propionic acid-treated rats display social behavior impairments $(112,113)$, altered brain lipid profiles (114), restricted behavioral interests and cognitive impairment (115), hypophagia and taste avoidance (116), DNA damage (117), as well as sexual dimorphism in regard to acoustic startle response and prepulse inhibition (118), all of which are implicated in human ASD. In addition, another group has shown that clindamycin-induced clostridia overgrowth causes propionic acid elevation and subsequent genotoxicity in the brain of hamsters (119), which supports the hypothesis of the gut origin of this metabolite. Propionic acid also affects colonic smooth muscle contraction, mast cell activation, serotonin release, and gastric motility (120); these factors could provide a direct connection between microbial metabolic activity and gastrointestinal symptom occurrence.

Propionic acid is capable of reacting with ammonia, another putrefactive product, to produce $\beta$-alanine (121). $\beta$-alanine is structurally similar to $\gamma$-aminobutyric acid (GABA), an inhibitory neurotransmitter. $\beta$-alanine has been found to be higher in children with ASD compared to controls (63), can function as a partial GABA antagonist (122) and can cross the blood brain barrier (123), making it another potential candidate for ASD symptom induction (121). Urea cycle disorders, characterized by hyperammonemia, can also present with confusion, bizarre behaviors, and autistic-like symptoms $(124,125)$. Finally, several other putrefactive metabolites have also been found to be elevated in the urine and feces of ASD patients including p-cresol (47, 108), p-cresylsulfate, p-cresylglucuronate (108) and ammonia (49). P-cresol and p-cresylsulfate levels were also positively associated with stereotypic and compulsive/repetitive behaviors in these children (108), as well as overall severity of autistic symptoms (47). Elevated levels of putrefactive metabolites have also been found in animal models of ASD including 3-(3-hydroxyphenyl)-3-hydroxypropionic acid, 4-hydroxyhippuric acid, 4-hydroxybenzoic acid (126) and 4-ethylphenylsulfate (127). Abnormally high concentrations of putrefactive metabolites in children with ASD compared to controls could not be explained by dietary intake as consumption of protein, sugar, starch, and fiber was similar between groups (49). These differences may be better explained by digestive capacity, the gut microbiota, and overproduction of putrefactive metabolites in children with ASD, compared to typically developing children.

\section{FACTORS AFFECTING PROTEIN DIGESTIBILITY}

\section{Inherent Properties of Proteins}

Dietary proteins display a wide range of susceptibility to digestive processes in the human gut depending on sequence, structure and the food matrix in which it is present: certain proteins (e.g., human $\beta$-casein) are easily hydrolyzed into amino acids in the small intestine, whereas others (e.g., wheat storage proteins like gliadin and gluten) are highly resistant to proteolysis (128). Protein digestibility depends on several factors, including size, charge, amino acid sequence, tertiary structure (129-131) and post-translational modifications such as glycosylation $(132,133)$ and phosphorylation (134). In general, even under idealized conditions, proteins from animal sources tend to be more susceptible to enzymatic hydrolysis and demonstrate apparent digestibility over 95\% with milk proteins having the highest apparent digestibility at around $98 \%$. Plant proteins have lower apparent digestibility with values ranging from 70 to $85 \%$. However, certain animal structural proteins, such as collagen, elastin, and keratin contain unusual secondary structures that are resistant to proteolysis (128). For example, the collagen triple helix is characterized by stabilizing crosslinks between peptide chains that are difficult to cleave and reduce digestibility. The low digestibility of plant proteins is partially due to similar structural features as well as relative insolubility, compact structures of intracellular protein bodies and high structural integrity of the plant cell wall and seed coat (128). Therefore, vegetable proteins, particularly those found in legumes and cereal grains, require cooking in addition to other processing methods to partially improve digestibility.

Beyond protein structure, dietary protein digestibility can be reduced by anti-nutritional factors that reduce protein bioavailability. These factors include protease inhibitors, tannins and phytates (128) that are commonly found in plant foods $(135,136)$. Trypsin inhibitors are found in many legumes (common bean, cow pea, lima bean, peanut, garden peas and soy beans) and cereal grains (wheat and barley) as well as potatoes and some squash. These inhibitors bind trypsin, and sometimes chymotrypsin, within the gut lumen to impair protein digestion (128). In addition, many of these anti-proteases are resistant to digestion and are also highly stable to thermal and acid denaturation and so can retain at least partial activity even with cooking $(137,138)$. Tannins are naturally occurring plant polyphenols that function to bind and precipitate proteins $(139,140)$ and are found at high levels in legumes, nuts and other minority cereals such as sorghum and barley as well as many types of fruits (136). However, fruit is not a major source of protein in the diet. Tannins have also been shown to reduce feed digestibility by directly inhibit enzymes in the intestines of ruminants (139) and through formation of tanninnutrient complexes $(141,142)$. Overall, high levels of tannins 
in livestock feed diminish weight gains, apparent digestibility and feed utilization efficiency, partially through their action in inhibiting protein digestion (143). Finally, phytates are mineralbinding molecules found in the kernels of cereal grains including wheat, maize, rice, barley, sorghum, oats, rye, and millet (135) that may also decrease protein digestibility (144).

\section{Protein Processing Effects}

The processing of commodities into foods has important effects on the digestibility of proteins. Both protein structure and anti-nutritional factors can be altered by food processing heat treatments $(128,145)$. Heat treatment can either increase or decrease protein digestibility depending on the type of protein, and the temperature and duration of treatment (128). For example, cooking increases digestibility of legume proteins, but the increase in temperature negatively affects enzymatic hydrolysis and solubility of sorghum $(146,147)$ and milk proteins, and negatively affects maize proteins $(146,147)$. In targeted applications, the effects, of protein thermolyzation on digestibility, have been explored extensively, for example in the context of milk proteins in infant formula, which often undergo extreme heat treatment (148). Interestingly, several studies have shown that extensive heat treatment of milk proteins (e.g., spray drying, in-can sterilization) results in various protein modifications (e.g., increased protein-lipid and proteinprotein interactions, increased denaturation, and formation of modified side chains) that reduces their digestibility both in vitro $(149-153)$ and in vivo $(153,154)$. Heat treatment of bovine milk to an extent similar to that used in the industrial sterilization and processing of yogurt, makes the casein protein more resistant to digestive processes; this resistance is hypothesized to be due to heat-induced aggregate formation (152). In addition, reaction of the amine functional group on free amino acids with a reducing sugar results in the formation of Maillard reaction products that can also inhibit proteolysis (153). The amino acid lysine is more susceptible to this reaction that other amino acids due to the presence of its $\varepsilon$-amine group. When lysine reacts with the milk sugar lactose, lactosyllysine forms and inhibits the activity of trypsin (153). Other Maillard reaction products were similarly been found to inhibit protein digestion. Furthermore, irradiation, alkaline processing, oxidation, high pressure processing, extrusion and freeze-thaw cycling of foods can also affect protein digestibility $(128,145)$. In addition to the other deleterious properties of ultra-processed foods [e.g., the presence of harmful additives, preservatives, colorants and other toxins (155)] the negative effects of certain processing techniques on dietary protein digestibility prompt consideration of the exclusion of specific foods and the inclusion of protein sources based on their digestibility by at risk individuals (e.g., minimally processed dairy, eggs, meat, and fish) in the diets of children with ASD.

\section{Intestinal Environment}

Beyond the effects of protein structure and processing on digestibility, the individual's digestive environment alters degree of protein digestion. Specifically, individuals vary in their digestive capacity based on the level and activity of luminal proteases and brush border peptidases, gastric and intestinal luminal $\mathrm{pH}$, and microbial proteolytic activity (145). For example, in chronic malnutrition, pancreatic proteases are depleted (156). Pancreatic insufficiency, as determined by reduced fecal elastase-1 levels ( $<200 \mu \mathrm{g} / \mathrm{g}$ stool), is also common in gastrointestinal disorders such as celiac disease in children (157) and adults (158) that is correlated with the presence of villous atrophy (159) but not nutritional status (160). Other intestinal disorders are also associated with a high incidence of pancreatic insufficiency including irritable bowel syndrome (161), Crohn's disease, ulcerative colitis (162), giardiasis- or cow milk-related enteropathy (163), and diarrhea of infancy (164). Newborn infants are at particularly high risk for pancreatic insufficiency. One study found that $43 \%$ of newborn term infants have low elastase- 1 levels that reach adult levels by 48 hours of life while preterm infants experience elastase- 1 levels $<30 \mu \mathrm{g} / \mathrm{g}$ that do not reach adult levels until 14 days of life (165). Studies have also found reduced chymotrypsin levels in the stool of prematurely born infants who are small for gestational age compared to prematurely born infants who are appropriately sized for their gestational age (166). Pancreatic insufficiency can also be induced by enteric pathogen colonization leading to acute enteritis in adults (167). In addition, low elastase-1 activity has also been found in diabetics (168) and the elderly (169). Pancreatic insufficiency has also been closely associated with increased markers of gastrointestinal inflammation (170), a common occurrence in children with ASD.

Impaired pancreatic function can be reversed, except for cases of severe and extensive malnutrition in which refeeding does not recover function $(171,172)$, other cases of pancreatic insufficiency are potentially reversible $(163,169)$. In the case of celiac disease, the reduced pancreatic exocrine function returns to normal after at least 12 months on a gluten-free diet (163). In addition, the symptoms of pancreatic insufficiency can be improved with enzyme supplementation (169). These observations suggest that it is possible to ameliorate digestive deficiency through enzyme supplementation as well as through implementation of personalized diets for individuals with reduced digestive capacity. For the fragile gut of children with ASD, this means a nutrient-rich diet containing appropriate protein sources.

The ability to routinely diagnose digestive issues is limited. The gold standard for assessment of pancreatic insufficiency (elastase-1 levels below $200 \mu \mathrm{g} / \mathrm{g}$ ) is an indirect measure of pancreatic exocrine function (173). One study (174) compared the fecal elastase-1 test with a direct assessment of pancreatic function, the pancreatic function test (PFT) (174). Results demonstrated that the correlation between the pancreatic function test and elastase-1 results were poor. The elastase1 test has a sensitivity of only $41.7 \%$, a specificity of $49.2 \%$ and a positive predictive value of only $14 \%$ (174). Thus, the incidence of pancreatic insufficiency is underestimated and the development of more sensitive indirect assessment tools is warranted. Furthermore, exocrine pancreatic function is only one dimension of protein digestive capacity and impairments in other aspects of this process are beginning to be explored (145). 


\section{LINKS BETWEEN GUT HEALTH AND BEHAVIOR}

It is now recognized that there is a connection between the health of the gut and the presence of psychiatric symptoms. For example, irritable bowel syndrome is associated with a high prevalence of depression, panic disorder, generalized anxiety and post-traumatic stress disorder (175). Explorations into the sources of these co-morbidities have led to hypotheses concerning the composition and activity of the gut microbiota and their interaction with the host immune system (176). There are several mechanisms by which the intestinal microbiota modulate the function of the central nervous system to influence mood and behavior including: augmentation of gut barrier integrity with subsequent changes in systemic levels of bacterial components and metabolites; synthesis of neuropeptides and other neurotransmitters; modification of local and systemic inflammation; moderation of absorbed nutrients, such as decreasing absorption of beneficial and essential nutrients (e.g., vitamins, short chain fatty acids, essential fatty acids, essential amino acids) while concomitantly increasing synthesis of detrimental compounds (e.g., putrefactive metabolites mentioned earlier); modulation of brain-derived neurotrophic factor; and regulation of microbial proliferation by increasing small bacterial overgrowth and/or gastric/intestinal pathogens (12). Thus, the composition and activity of the gut microbiota during critical periods of development has a profound influence on both the development of immune function and the development of the central nervous system in children with ASD as well. However, causation cannot be implied based on this observation. Treatment of children with ASD with oral vancomycin (an antibiotic not readily absorbed by the gastrointestinal tract and thus limited in its effect to the gut lumen) has a short-term benefit for some symptoms of autism in some individuals (177), which is expected if certain microbial pathogens are contributing to behavioral symptoms. Therefore, the presence of gut microbial dysbiosis during critical periods of development has an impact on both immune and neurodevelopment. Early dietary considerations must be taken into account to promote the proper development of these systems.

\section{EFFICACY OF RESTRICTED DIETS}

Given the general detrimental effect that consumption of proteins with low digestibility could have in children with ASD, examination of studies that consider diets where several of these proteins are eliminated can provide insight into the hypothesis of impaired protein digestive capacity in this cohort even when specific mechanisms of action have not been determined. Several observational and clinical studies looking at the effect of specific protein-free diets, such as GFCF, have reported mixed results in regard to benefit in reduction of gastrointestinal symptoms and behavioral problems (178). Multiple studies have reported significant beneficial effects of the GFCF diet including normalization of urinary peptide levels (179), reduced intestinal permeability (25), and overall improvement of behavioral metrics (179-183). ASD children with gastrointestinal disturbances have been found to show greater improvement in ASD behaviors (e.g., self-stimulatory behaviors, hyperactivity, sensory seeking behaviors, temper tantrums, lining up objects, and echolalia), physiological symptoms (e.g., bodily rash, red ring around anus, constipation, diarrhea and seizures), and social behaviors (e.g., social responsiveness, eye contact, engagement, attention span, requesting behavior, naming objects, pointing, language production, and imaginative play) on the GFCF diet compared to children with ASD but without overt gastrointestinal symptoms (183).

There are important limitations to all dietary intervention studies conducted in this field, such as short duration of treatment ( $<1$ year), heterogeneous sampling (did not select for patients with gastrointestinal symptoms), lack of reporting of changes in gastrointestinal symptoms, and lack of testing for compliance, which is important considering that these proteins are ubiquitous in the modern diet. Indeed, strict implementation of the diet has resulted in substantially greater improvement ASD behaviors, physiological symptoms, and social behaviors (183). In addition, there are likely other dietary proteins that are similarly difficult to digest that have not been considered and need to be minimized in cases of a fragile gut. Overall, dietary intervention studies in these children have not been able to address the multiple, integrated consequences of inappropriate proteins in the diets of individuals with ASD, including dietary protein digestion, gut-associated immune responses, and potential perturbations to the intestinal microbiota, much less provide the diagnostics to build tailored solutions. The future of research in this area will require investigation of whole food components, as gluten-free/casein-free diets are actually wheatfree/dairy-free, and thus food needs to be the focus rather than isolated dietary components.

\section{FACTORS AFFECTING FOOD CHOICE AFFECT PROTEIN CONSUMPTION IN CHILDREN WITH AUTISM}

Children with ASD are notoriously "picky eaters"; they have particularly strong food aversions and can be ultrasensitive to food context, especially texture (184-186). Specifically, this cohort has a high oral sensitivity level $(184,187)$, which means that the children will choose, crave, and avoid certain food smells, tastes, temperatures, and textures (184). For example, it has been observed that children with ASD are less likely to be able to identify sour or bitter tastes and have a decreased olfactory sense compared to typically developing children (188).

Along with an oral sensitivity, children with ASD have lower facial feedback when performing pleasurable tasks that induce laughter or other positive reactions normally seen in typically developing children (189). This decreased facial feedback could have an impact on the way that these children consume foods. One research study proposed that texture preference is based on the sensation received from mouth movements, such as whether the food is chewed, crunched, smushed, or sucked (190). 
Sensorial properties of foods are important, especially in children with ASD, since proteins affect food texture and are not homogenous in the diet. Different food commodities provide various types of proteins with varying configurations, including differences in amino acid composition as well as secondary and tertiary structure. Some dietary proteins are easily broken down completely into their constitutive amino acids during digestion in the small intestine, whereas others are more resistant to digestion (128). These proteins can survive intact or partially intact to the colon where they serve as a food source for putrefactive bacteria (191). However, consumers typically select and ingest proteins not on the basis of digestibility, but rather on their sensorial properties.

Palatability varies and is dependent upon food processing methods that alter protein texture and structure. For instance, there are many industrial meat processing techniques that change the texture and the palatability of the meat such as, the use of a pulsed electric field that perturbs cellular architecture (192), the preparation of meat batter at high temperatures that denatures myosin and myofibrillar proteins (193), and the adjustment of $\mathrm{pH}$ that alters meat tenderization properties (194). Additionally, dairy product treatments affect palatability by changing the structures of proteins and lipids. For example, sonication of dairy products disrupts protein composition (195), and homogenization and heat treatment cause increased protein-lipid interaction and disruption of milk fat globule structure (153). Therefore, processing of meat and dairy products could alter chemical structures in these foods and may reduce palatability for groups particularly sensitive to food texture, such as children with ASD.

The necessity to implement personalized diets based on an assessment of individual responses to different protein sources in this population is crucial given this populations' tendency toward food aversions, preferences and dietary needs. Occasionally, children with ASD consume inadequate amounts of protein. While there is limited research on differences in protein intake in affected children, one study found that $42.1 \%$ of autistic children consume inadequate amounts of proteins (defined as $<77 \%$ of the daily recommended intake) (186). While other studies have shown no differences in intake level (196), some have shown decreased protein consumption in ASD children compared to other family members (197). In addition, proteincontaining foods were least preferred by the children with ASD as $67.4 \pm 18.7 \%$ of the children studied were reported to "never consume" them. Comparatively, foods high in starches were most preferred as only $44.2 \pm 22 \%$ of the children with ASD never consumed them (186). However, these studies are extremely limited and protein source/processing has not been considered. In another study, children with autism were reported to consume significantly fewer foods in dairy $(p=0.001)$ and protein $(p=0.001)$ categories than typically developing children (198). In addition, there was no difference in the number of foods consumed from each food category by families which suggests it was not the family's eating habits having the effect (198). In view of this review's hypothesis, if children have an immune reaction to certain dietary proteins, they would develop aversions to foods high in protein. Neural pathways from the brain may be altered in response to the immune activation from indigestible proteins in the fragile gut (199). If indigestible proteins are a contributing cause of inflammation, then a personalized diet that avoids specific proteins would be beneficial. Future advancements in the development of personalized diets will need to look for diagnostic tools capable of determining the effects of specific protein consumption in this cohort. To ensure compliance, the organoleptic and sensorial properties of foods and the taste preferences of the ASD individual into account. Well-annotated databases of nutritional requirements and taste preferences need to be integrated in order to design personalized diets.

\section{POTENTIAL TREATMENT OPTIONS}

\section{Probiotic Supplementation}

Probiotics, as defined by the WHO in 2001 (200), are "live microorganisms which, when administered in adequate amounts, confer a health benefit on the host." They are often, but not always, lactic-acid producing bacteria, such as lactobacilli, lactococci, and bifidobacteria, or yeasts such as "saccharomyces boulardii" (201). While probiotic therapy has been suggested in multiple reviews as a potential treatment for children with ASD and gastrointestinal symptoms (1), there have been no randomized controlled trials of this type of intervention in this cohort to date. Even so, it has been reported that as of 2009 , one-fifth of physicians encourages use of probiotics for children with ASD (202). One study showed that Lactobacillus acidophilus administration $\left(5 \times 10^{9} \mathrm{CFU} /\right.$ day, twice a day for 2 months) significantly reduced a marker of invasive pathogenic candidiasis in children with ASD and gastrointestinal symptoms (203). However, half of the children in the study were on restricted diets and the study design lacked a control group. A separate observational study demonstrated reduced levels of myeloperoxidase, a marker of inflammation and oxidation, in children with ASD and gastrointestinal symptoms who were undergoing probiotic therapy compared to similar children not taking probiotics (204). Probiotic supplementation has been used in animal models of autism with efficacy. Hsiao et al. (127) demonstrated gastrointestinal barrier defects and microbiota abnormalities in a maternal immune activation (MIA) mouse model of ASD. Oral treatment for offspring with MIA with the human probiotic "Bacteroides fragilis" (" $B$. fragilis") not only increased gut barrier integrity and reversed some microbial alterations, but also ameliorated certain behavioral deficits. Defects in communicative, stereotypic, anxiety-like and sensorimotor behaviors were significantly improved with probiotic administration. Therefore, further investigation into the role of probiotic supplementation in children with ASD and gastrointestinal symptoms via properly designed randomized controlled trials that correlate behavioral and physiological outcomes is warranted.

\section{Digestible Proteins}

A treatment option for children with ASD and gastrointestinal symptoms is to replace indigestible proteins in the diet with more digestible sources. While GFCF, diets (which are actually wheat-free/dairy-free) have shown some efficacy in reducing 
ASD associated gastrointestinal co-morbidities, as previously mentioned, the effect is often marginal with some studies showing greater benefit than others (25, 178-183). Ambiguity in outcomes may in part be due to the simple fact that these dietary protein sources are replaced by alternative protein sources that are also indigestible, such as maize, legumes and other plant-based proteins. In addition, these glutenfree options also tend to be high in refined carbohydrates and also promote bacterial dysbiosis in the fragile ASD gut. In order to increase the efficacy of the GFCF diet, protein sources need to be replaced by highly digestible protein. Many researchers and clinicians hesitate to recommend restricted diets for children with ASD due to dietary imbalances, sensory preferences and low protein intakes that may result from this recommendation (205). However, a properly designed diet that includes digestible protein sources, as well as recommended amounts of vitamins and minerals, can be implemented to improve gastrointestinal function and nutritional status in children with ASD. Combination treatments that utilize high quality protein diets and appropriate complex carbohydrate intake, would promote beneficial bacterial colonization, increase saccharolytic fermentation, reduce microbial putrefaction and subsequently normalize gut inflammation and permeability. This improved gut function could result in reduced ASD symptoms that are a consequence of circulating putrefactive and inflammatory bacterial metabolites as well as diet-derived autoantibodies on nervous system function in children with ASD and gastrointestinal co-morbidities.

\section{Digestive Enzymes}

If digestive capacity is impaired in a subset of children with ASD, another potential treatment option is digestive enzyme supplementation, specifically with a full panel of proteases. A limited number of studies have been conducted to test the efficacy of digestive enzyme supplementation on gastrointestinal and behavioral outcomes in children with ASD. One study (206) utilized a unique combination of proteases called ENZYMAID that included alpha-fetoprotein (AFP), bromelain, CASE-GLUTINASE, and phytase (206). AFP is acid-stable and breaks up large proteins into peptides in the stomach, bromelain is a combination of proteolytic enzymes found in pineapple, CASE-GLUTINASE contains both exo- and endopeptidases and has DPP-IV activity, and phytase acts to break down phytate (a plant mineral-binding protein) in order to increase mineral bioavailability. Significant improvement in all parameters measured was observed including eye contact, attention, mood, anxiety/compulsion, comprehension, digestion, and sleep. The most significant improvements were observed in socialization ( $90 \%$ improved) and hyperactivity (80\% improved) (206). A more recent study corroborated these findings using Neo-Digestion oral solution containing papain and pepsin (207). Results found significant improvements in emotional response, general autistic impression scores, general behavior and gastrointestinal symptoms including stool quality, abdominal pain, vomiting and food variety. The main behavioral improvements included less restricted and repetitive behavior as well as stereotypic behavior. No correlation was observed between behavior improvement and gastrointestinal symptom improvement, suggesting that behaviors did not improve simply due to lessening of gastrointestinal symptoms (207). While another study found no benefit of enzyme supplementation, this study did not control for probiotic use, which was noted for some subjects (208). Previous studies have shown that some probiotic products contain bacterial strains with potent DPP-IV activity (206), which could confound the results.

\section{SUMMARY AND CONCLUSIONS}

In conclusion, impaired gut immune and digestive function, high levels of circulating dietary peptides, presence of autoantibodies that cross react with dietary proteins, increased levels of putrefactive metabolites with potent actions on gut and behavior, and the microbial patterns associated with ASD, such as high prevalence of clostridial species and high ratios of Firmicutes to Bacteroidetes, suggest that protein-driven microbial dysbiosis exacerbates both gastrointestinal and ASD symptoms. In general, saccharolytic microbes that thrive off of dietary glycans (such as fermentable fibers) tend to produce short chain fatty acids, lower the $\mathrm{pH}$ of the intestine, lower pathogens and promote the maturation and metabolism of gut epithelial cells. In contrast, proteolytic microbes that thrive off of incompletely digested dietary proteins produce byproducts such as ammonia, amines, phenols, and sulfides that have a negative effect on gut health (102) and brain function (120). Therefore, the consumption of dietary proteins that are difficult to digest by the reduced digestive capacity of the fragile ASD intestine results in elevated levels of peptides in the gut. These aberrant peptides have the potential to negatively affect gut barrier integrity, feed proteolytic bacteria that produce harmful byproducts, and set off an aberrant immune response, either directly or through the promotion of bacterial dysbiosis. Microbial dysbiosis can promote further improper activation of the immune system leading to a vicious cycle of dysbiosis, inflammation and further damage to gastrointestinal tissue and function. The working hypothesis is that children with ASD experience reduced proteolytic capacity that leads to colonic putrefaction that causes gastrointestinal problems that exacerbate ASD symptoms (Figure 1). Therefore, characterizing the digestive capacity of children with ASD is a personalization strategy capable of guiding diets to include appropriate source and processing methods for dietary proteins. This style of personal intervention will allow for the design and implementation of individualized diets, with particular consideration of protein source and processing, to improve gastrointestinal function and promote a beneficial microbial composition in children with ASD.

Understanding the gut etiology of disease has been hindered by technological and clinical limitations that have inhibited advancements in the field of dietary protein digestion. The application of peptidomics will allow for characterization of protein digestion site, specifically within the gastrointestinal tract. Currently, protein digestion is viewed as a single event definable in very narrow terms when, in fact, digestion is a very broad process varying in multiple aspects of space 
and time. Recent technological advancements in the area of proteomics and peptidomics now provide the capabilities to perform extensive characterization of digestive processes occurring continually along the length of the small intestine (209-212). Likewise, the technologies to map protein digestion in the gut-peptidomics-is only recently emerging (211, 213). The development of innovations for sampling the human gut, the progression of improvements in peptidomics, and the application of biomarkers for protein digestion (including metabolomics, microbial sequencing and multiplexed inflammatory protein monitoring), will enhance understanding in this field. Specifically, these innovations will improve knowledge of dietary proteins' digestive processes in specific sections of the gut in various populations. Intestinal protein digestion can affect regulatory processes, immune development, and microbial colonization, especially during the perinatal period, and in other susceptible populations where inadequate digestion is particularly harmful.

Further research in this area should expand on the current body of literature that has focused on determining associations between gut function and ASD symptoms to include experimental and clinical studies designed to determine causal relationships between these factors. These studies will have broad implications to many diseases associated with gastrointestinal function, and knowledge gained will play a crucial role in the design of personalized diets with protein sources tailored to individuals with a fragile gut.

\section{REFERENCES}

1. Critchfield JW, van Hemert S, Ash M, Mulder L, Ashwood P. The potential role of probiotics in the management of childhood autism spectrum disorders. Gastroenterol Res Pract. (2011) 2011:161358. doi: $10.1155 / 2011 / 161358$

2. de Theije CG, Wu J, da Silva SL, Kamphuis PJ, Garssen J, Korte SM, et al. Pathways underlying the gut-to-brain connection in autism spectrum disorders as future targets for disease management. Eur J Pharmacol. (2011) 668(Suppl. 1):S70-80. doi: 10.1016/j.ejphar.2011.07.013

3. Kral TV, Eriksen WT, Souders MC, Pinto-Martin JA. Eating behaviors, diet quality, and gastrointestinal symptoms in children with autism spectrum disorders: a brief review. J Pediatr Nurs. (2013) 28:548-56. doi: 10.1016/j.pedn.2013.01.008

4. Christensen DL, Baio J, Van Naarden Braun K, Bilder D, Charles J, Constantino JN, et al. Prevalence and characteristics of autism spectrum disorder among children aged 8 years-autism and developmental disabilities monitoring network, 11 sites, United States, 2012. MMWR Surveill Summ. (2016) 65:1-23. doi: 10.15585/mmwr.ss6503a1

5. Hertz-Picciotto I, Delwiche L. The rise in autism and the role of age at diagnosis. Epidemiology (2009) 20:84-90. doi: 10.1097/EDE.0b01 $3 \mathrm{e} 3181902 \mathrm{~d} 15$

6. Le Couteur A, Lord C, Rutter M. The Autism Diagnostic Interview - Revised (ADI-R). Los Angeles, CA: Western Psychological Services (2003).

7. Lord C, Risi S, Lambrecht L, Cook, E. H. Jr., Leventhal BL, DiLavore PC, et al. The autism diagnostic observation schedule-generic: a standard measure of social and communication deficits associated with the spectrum of autism. J Autism Dev Disord. (2000) 30:205-23. doi: 10.1023/A:1005592 401947

8. Rossignol DA, Frye RE. A review of research trends in physiological abnormalities in autism spectrum disorders: immune dysregulation, inflammation, oxidative stress, mitochondrial dysfunction and

\section{AUTHOR CONTRIBUTIONS}

MS wrote the manuscript based on her original ideas and designed the figure. JK wrote sections of the manuscript and created the figure. KA contributed to the overall concept of the manuscript and provided content expertise on ASD and behavioral symptoms, and JG revised the work critically for important intellectual content and provided approval for publication of the content. All authors have read and approved the final version of the manuscript.

\section{FUNDING}

This work was supported, in part, by funding from National Institutes of Health awards \#R01AT007079 and \#R01AT008759 and National Center for Advancing Translational Sciences, National Institutes of Health \#TL1 TR000133 and \#NIH AT006180.

\section{ACKNOWLEDGMENTS}

We would like to thank Helen Raybould for her support and assistance with editing and organization of the document. We would also like to thank David Dallas for his help with formatting the document. We would also like to thank Stephen Frese for his expertise and consultation in interpretation of gut microbiota studies in ASD.

environmental toxicant exposures. Mol Psychiatry (2012) 17:389-401. doi: $10.1038 / \mathrm{mp} .2011 .165$

9. Gesundheit B, Rosenzweig JP, Naor D, Lerer B, Zachor DA, Prochazka V, et al. Immunological and autoimmune considerations of Autism Spectrum Disorders. J Autoimmun (2013) 44:1-7. doi: 10.1016/j.jaut.2013.05.005

10. Lyall K, Schmidt RJ, Hertz-Picciotto I. Maternal lifestyle and environmental risk factors for autism spectrum disorders. Int J Epidemiol. (2014) 43:443-64. doi: 10.1093/ije/dyt282

11. Buie T. Potential etiologic factors of microbiome disruption in autism. Clin Ther. (2015) 37:976-83. doi: 10.1016/j.clinthera.2015.04.001

12. Fond G, Boukouaci W, Chevalier G, Regnault A, Eberl G, Hamdani $\mathrm{N}$, et al. The psychomicrobiotic: targeting microbiota in major psychiatric disorders: a systematic review. Pathol Biol. (2015) 63:35-42. doi: 10.1016/j.patbio.2014.10.003

13. Mead J, Ashwood P. Evidence supporting an altered immune response in ASD. Immunol Lett. (2015) 163:49-55. doi: 10.1016/j.imlet.2014.11.006

14. McElhanon BO, McCracken C, Karpen S, Sharp WG. Gastrointestinal symptoms in autism spectrum disorder: a meta-analysis. Pediatrics (2014) 133:872-83. doi: 10.1542/peds.2013-3995

15. Adams JB, Johansen LJ, Powell LD, Quig D, Rubin RA. Gastrointestinal flora and gastrointestinal status in children with autism-comparisons to typical children and correlation with autism severity. BMC Gastroenterol. (2011) 11:22. doi: 10.1186/1471-230X-11-22

16. Nikolov RN, Bearss KE, Lettinga J, Erickson C, Rodowski M, Aman $\mathrm{MG}$, et al. Gastrointestinal symptoms in a sample of children with pervasive developmental disorders. J Autism Dev Disord. (2009) 39:405-13. doi: 10.1007/s10803-008-0637-8

17. Bull MJ, Plummer NT. Part 1: the human gut microbiome in health and disease. Integr Med. (2014) 13:17-22.

18. Melmed R, Schneider C, Fabes R, Philips J, Reichelt K. Metabolic markers and gastrointestinal symptoms in children with autism and related disorders. J Pediatr Gastroenterol Nutr. (2000) 31(Suppl. 2):S31. 
19. Valicenti-McDermott M, McVicar K, Rapin I, Wershil BK, Cohen H, Shinnar S. Frequency of gastrointestinal symptoms in children with autistic spectrum disorders and association with family history of autoimmune disease. J Dev Behav Pediatr. (2006) 27(Suppl. 2):S128-36. doi: 10.1097/00004703-200604002-00011

20. Buie T, Campbell DB, Fuchs, G. J. I. I. I., Furuta GT, Levy J, Vandewater $\mathrm{J}$, et al. Evaluation, diagnosis, and treatment of gastrointestinal disorders in individuals with ASDs: a consensus report. Pediatrics (2010) 125(Suppl. 1):S1-18. doi: 10.1542/peds.2009-1878C

21. Wang L, Christophersen CT, Sorich MJ, Gerber JP, Angley MT, Conlon MA. Low relative abundances of the mucolytic bacterium Akkermansia muciniphila and Bifidobacterium spp. in feces of children with autism. Appl Environ Microbiol. (2011) 77:6718-21. doi: 10.1128/AEM.05212-11

22. Gurney JG, McPheeters ML, Davis MM. Parental report of health conditions and health care use among children with and without autism: National Survey of Children's Health. Arch Pediatr Adolesc Med. (2006) 160:825-30. doi: 10.1001 /archpedi.160.8.825

23. Furlano RI, Anthony A, Day R, Brown A, McGarvey L, Thomson MA, et al. Colonic CD (2001) 8 and gamma delta T-cell infiltration with epithelial damage in children with autism. J Pediatr. 138:366-72. doi: $10.1067 / \mathrm{mpd} .2001 .111323$

24. D’Eufemia P, Celli M, Finocchiaro R, Pacifico L, Viozzi L, Zaccagnini M, et al. Abnormal intestinal permeability in children with autism. Acta Paediatry (1996) 85:1076-79. doi: 10.1111/j.1651-2227.1996.tb14220.x

25. de Magistris L, Familiari V, Pascotto A, Sapone A, Frolli A, Iardino P, et al. Alterations of the intestinal barrier in patients with autism spectrum disorders and in their first-degree relatives. J Pediatr Gastroenterol Nutr. (2010) 51:418-24. doi: 10.1097/MPG.0b013e3181dcc4a5

26. Ashwood P, Anthony A, Pellicer AA, Torrente F, Walker-Smith JA, Wakefield AJ. Intestinal lymphocyte populations in children with regressive autism: evidence for extensive mucosal immunopathology. J Clin Immunol. (2003) 23:504-17. doi: 10.1023/B:JOCI.0000010427.05143.bb

27. Ashwood P, Anthony A, Torrente F, Wakefield AJ. Spontaneous mucosal lymphocyte cytokine profiles in children with autism and gastrointestinal symptoms: mucosal immune activation and reduced counter regulatory interleukin-10. J Clin Immunol. (2004) 24:664-73. doi: 10.1007/s10875-004-6241-6

28. Torrente F, Ashwood P, Day R, Machado N, Furlano RI, Anthony A, et al. Small intestinal enteropathy with epithelial IgG and complement deposition in children with regressive autism. Mol Psychiatry (2002) 7:375-82, 334. doi: $10.1038 /$ sj.mp.4001077

29. Warren RP, Margaretten NC, Pace NC, Foster A. Immune abnormalities in patients with autism. J Autism Dev Disord. (1986) 16:189-97. doi: 10.1007/BF01531729

30. Warren RP, Foster A, Margaretten NC. Reduced natural killer cell activity in autism. J Am Acad Child Adolesc Psychiatry (1987) 26:333-5. doi: 10.1097/00004583-198705000-00008

31. Gupta S, Aggarwal S, Rashanravan B, Lee T. Th1- and Th2-like cytokines in CD4+ and CD8+ T cells in autism. J Neuroimmunol. (1998) 85:106-9. doi: 10.1016/S0165-5728(98)00021-6

32. Ashwood P, Wakefield AJ. Immune activation of peripheral blood and mucosal CD3+ lymphocyte cytokine profiles in children with autism and gastrointestinal symptoms. J Neuroimmunol. (2006) 173:126-34. doi: 10.1016/j.jneuroim.2005.12.007

33. Jyonouchi H, Geng L, Ruby A, Reddy C, Zimmerman-Bier B. Evaluation of an association between gastrointestinal symptoms and cytokine production against common dietary proteins in children with autism spectrum disorders. J Pediatr. (2005) 146:605-10. doi: 10.1016/j.jpeds.2005.0 1.027

34. Jyonouchi H, Geng L, Ruby A, Zimmerman-Bier B. Dysregulated innate immune responses in young children with autism spectrum disorders: their relationship to gastrointestinal symptoms and dietary intervention. Neuropsychobiology (2005) 51:77-85. doi: 10.1159/0000 84164

35. Montgomery RK, Mulberg AE, Grand RJ. Development of the human gastrointestinal tract: Twenty years of progress. Gastroenterology (1999) 116:702-31. doi: 10.1016/S0016-5085(99)70193-9
36. Steinert A, Radulovic K, Niess J. Gastro-intestinal tract: The leading role of mucosal immunity. Swiss Med Wkly (2016) 146:w14293. doi: 10.4414/smw.2016.14293

37. Chahine BG, Bahna SL. The role of the gut mucosal immunity in the development of tolerance against allergy to food. Curr Opin Allergy Clin Immunol. (2010) 10:220-5. doi: 10.1097/ACI.0b013e32833982ab

38. Spreckley E, Murphy KG. The L-cell in nutritional sensing and the regulation of appetite. Front Nutr. (2015) 2:23. doi: 10.3389/fnut.2015.00023

39. Finegold SM, Molitoris D, Song Y, Liu C, Vaisanen ML, Bolte E, et al. Gastrointestinal microflora studies in late-onset autism. Clin Infect Dis. (2002) 35(Suppl. 1):S6-16. doi: 10.1086/341914

40. Song Y, Liu C, Finegold SM. Real-time PCR quantitation of clostridia in feces of autistic children. Appl Environ Microbiol. (2004) 70:6459-65. doi: 10.1128/AEM.70.11.6459-6465.2004

41. Parracho HM, Bingham MO, Gibson GR, McCartney AL. Differences between the gut microflora of children with autistic spectrum disorders and that of healthy children. J Med Microbiol. (2005) 54(Pt 10):987-91. doi: 10.1099/jmm.0.46101-0

42. Finegold SM, Dowd SE, Gontcharova V, Liu C, Henley KE, Wolcott RD, et al. Pyrosequencing study of fecal microflora of autistic and control children. Anaerobe (2010) 16:444-53. doi: 10.1016/j.anaerobe.2010.06.008

43. Williams BL, Hornig M, Buie T, Bauman ML, Cho Paik M, Wick I, et al. Impaired carbohydrate digestion and transport and mucosal dysbiosis in the intestines of children with autism and gastrointestinal disturbances. PLoS ONE (2011) 6:e24585. doi: 10.1371/journal.pone.0024585

44. Kang DW, Park JG, Ilhan ZE, Wallstrom G, Labaer J, Adams JB, et al. Reduced incidence of Prevotella and other fermenters in intestinal microflora of autistic children. PLoS ONE (2013) 8:e68322. doi: 10.1371/journal.pone.0068322

45. De Angelis M, Piccolo M, Vannini L, Siragusa S, De Giacomo A, Serrazzanetti DI, et al. Fecal microbiota and metabolome of children with autism and pervasive developmental disorder not otherwise specified. PLoS ONE (2013) 8:e76993. doi: 10.1371/journal.pone.0076993

46. Shaw W. Increased urinary excretion of a 3-(3-hydroxyphenyl)-3hydroxypropionic acid (HPHPA), an abnormal phenylalanine metabolite of Clostridia spp. in the gastrointestinal tract, in urine samples from patients with autism and schizophrenia. Nutr Neurosci. (2010) 13:135-43. doi: 10.1179/147683010X12611460763968

47. Altieri L, Neri C, Sacco R, Curatolo P, Benvenuto A, Muratori F, et al. Urinary $\mathrm{p}$-cresol is elevated in small children with severe autism spectrum disorder. Biomarkers (2011) 16:252-60. doi: 10.3109/1354750X.2010.548010

48. Al-Owain M, Kaya N, Al-Shamrani H, Al-Bakheet A, Qari A, Al-Muaigl S, et al. Autism spectrum disorder in a child with propionic acidemia. JIMD Rep (2013) 7:63-6.doi: 10.1007/8904_2012_143

49. Wang L, Christophersen CT, Sorich MJ, Gerber JP, Angley MT, Conlon MA. Elevated fecal short chain fatty acid and ammonia concentrations in children with autism spectrum disorder. Dig Dis Sci. (2012) 57:2096-102. doi: 10.1007/s10620-012-2167-7

50. Gabriele S, Sacco R, Altieri L, Neri C, Urbani A, Bravaccio C, et al. Slow intestinal transit contributes to elevate urinary p-cresol level in Italian autistic children. Autism Res. (2015) 9:752-9. doi: 10.1002/aur.1571

51. Horvath K, Papadimitriou JC, Rabsztyn A, Drachenberg C, Tildon JT. Gastrointestinal abnormalities in children with autistic disorder. J Pediatr. (1999) 135:559-63. doi: 10.1016/S0022-3476(99)70052-1

52. Williams K, Wray JA, Wheeler DM.. Intravenous secretin for autism spectrum disorders (ASD). Cochrane Database Syst Rev. (2012) 18:Cd003495. doi: 10.1002/14651858.CD003495.pub3

53. Johansson C, Schmidt DN, Hellstrom PM. Changed integrated gastrointestinal response to a mixed meal in exocrine pancreatic insufficiency. Pancreas (1992) 7:205-211. doi: 10.1097/00006676-199203000-00012

54. Balas D, Senegas-Balas F, Bertrand C, Frexinos J, Ribet A. Effects of pancreatic duct ligation on the hamster intestinal mucosa. Histological findings. Digestion (1980) 20:157-167. doi: 10.1159/000198435

55. Senegas-Balas F, Bastie MJ, Balas D, Escourrou J, Bommelaer G, Bertrand C, et al. Histological variations of the duodenal mucosa in chronic human pancreatitis. Dig Dis Sci. (1982) 27:917-22. doi: 10.1007/BF01316576 
56. Reichelt KL, Knivsberg AM. Can the pathophysiology of autism be explained by the nature of the discovered urine peptides? Nutr Neurosci. (2003) 6:19-28. doi: 10.1080/1028415021000042839

57. Reichelt KL, Knivsberg AM, Lind G, Nødland M. Probable etiology and possible treatment of childhood autism. Brain Dysfunct. (1991) 4:308-19.

58. Reichelt KL, Knivsberg AM. The possibility and probability of a gut-to-brain connection in autism. Ann Clin Psychiatry (2009) 21:205-11.

59. Reichelt KL, Tveiten D, Knivsberg AM, Bronstad G. Peptides' role in autism with emphasis on exorphins. Microb Ecol Health Dis (2012) 23:18958. doi: 10.3402/mehd.v23i0.18958

60. Mahe S, Tome D, Dumontier AM, Desjeux JF. Absorption of intact morphiceptin by diisopropylfluorophosphate-treated rabbit ileum. Peptides (1989) 10:45-52. doi: 10.1016/0196-9781(89)90074-0

61. Watanabe Y, Kojima-Komatsu T, Iwaki-Egawa S, Fujimoto Y. Increased excretion of proline-containing peptides in dipeptidyl peptidase IV-deficient rats. Res Commun Chem Pathol Pharmacol. (1993) 81:323-30.

62. Moreno-Fuenmayor H, Borjas L, Arrieta A, Valera V, Socorro-Candanoza L. Plasma excitatory amino acids in autism. Invest Clin. (1996) 37:113-28.

63. Aldred S, Moore KM, Fitzgerald M, Waring RH. Plasma amino acid levels in children with autism and their families. J Autism Dev Disord. (2003) 33:93-7. doi: 10.1023/A:1022238706604

64. Rolf LH, Haarmann FY, Grotemeyer KH, Kehrer H. Serotonin and amino acid content in platelets of autistic children. Acta Psychiatr Scand. (1993) 87:312-6. doi: 10.1111/j.1600-0447.1993.tb03378.x

65. Arnold GL, Hyman SL, Mooney RA, Kirby RS. Plasma amino acids profiles in children with autism: potential risk of nutritional deficiencies. J Autism Dev Disord. (2003) 33:449-54. doi: 10.1023/A:1025071014191

66. Adams JB, Audhya T, McDonough-Means S, Rubin RA, Quig D, Geis E, et al. Nutritional and metabolic status of children with autism vs. neurotypical children, and the association with autism severity. Nutr Metab. (2011) 8:34. doi: $10.1186 / 1743-7075-8-34$

67. Rojas DC. The role of glutamate and its receptors in autism and the use of glutamate receptor antagonists in treatment. J Neural Transm. (2014) 121:891-905. doi: 10.1007/s00702-014-1216-0

68. Jaiswal P, Mohanakumar KP, Rajamma U. Serotonin mediated immunoregulation and neural functions: complicity in the aetiology of autism spectrum disorders. Neurosci Biobehav Rev. (2015) 55:413-31. doi: 10.1016/j.neubiorev.2015.05.013

69. Kriete T, Noelle DC. Dopamine and the development of executive dysfunction in autism spectrum disorders. PLoS ONE (2015) 10:e0121605. doi: 10.1371/journal.pone.0121605

70. Vojdani A, Campbell AW, Anyanwu E, Kashanian A, Bock K, Vojdani E. Antibodies to neuron-specific antigens in children with autism: possible cross-reaction with encephalitogenic proteins from milk, Chlamydia pneumoniae and Streptococcus group A. J Neuroimmunol. (2002) 129:16877. doi: 10.1016/S0165-5728(02)00180-7

71. Vojdani A, Pangborn JB, Vojdani E, Cooper EL. Infections, toxic chemicals and dietary peptides binding to lymphocyte receptors and tissue enzymes are major instigators of autoimmunity in autism. Int J Immunopathol Pharmacol. (2003) 16:189-99. doi: 10.1177/039463200301600302

72. Vojdani A, Bazargan M, Vojdani E, Samadi J, Nourian AA, Eghbalieh $\mathrm{N}$, et al. Heat shock protein and gliadin peptide promote development of peptidase antibodies in children with autism and patients with autoimmune disease. Clin Diagn Lab Immunol. (2004) 11:515-24. doi: 10.1128/CDLI.11.3.515-524.2004

73. Lucarelli S, Frediani T, Zingoni A, Ferruzzi F, Giardini O, Quintieri F, et al. Food allergy and infantile autism. Panmin Med. (1995) 37:137-41.

74. Vojdani A, O’Bryan T, Green JA, McCandless J, Woeller KN, Vojdani $\mathrm{E}$, et al. Immune response to dietary proteins, gliadin and cerebellar peptides in children with autism. Nutr Neurosci. (2004) 7:151-61. doi: $10.1080 / 10284150400004155$

75. de Magistris L, Picardi A, Siniscalco D, Riccio MP, Sapone A, Cariello R, et al. Antibodies against food antigens in patients with autistic spectrum disorders. Biomed Res Int. (2013) 2013:729349. doi: 10.1155/2013/729349

76. Singh VK, Warren RP, Odell JD, Warren WL, Cole P. Antibodies to myelin basic protein in children with autistic behavior. Brain Behav Immun. (1993) 7:97-103. doi: 10.1006/brbi.1993.1010
77. Singh VK, Warren R, Averett R, Ghaziuddin M. Circulating autoantibodies to neuronal and glial filament proteins in autism. Pediatr Neurol. (1997) 17:88-90. doi: 10.1016/S0887-8994(97)00045-3

78. Braunschweig D, Ashwood P, Krakowiak P, Hertz-Picciotto I, Hansen R, Croen LA, et al. Autism: maternally derived antibodies specific for fetal brain proteins. Neurotoxicology (2008) 29:226-31. doi: 10.1016/j.neuro.2007.10.010

79. Bauman MD, Iosif AM, Ashwood P, Braunschweig D, Lee A, et al. and Amaral DG, et al. Maternal antibodies from mothers of children with autism alter brain growth and social behavior development in the rhesus monkey. Transl Psychiatry (2013) 3:e278. doi: 10.1038/tp.2013.47

80. Braunschweig D, Krakowiak P, Duncanson P, Boyce R, Hansen RL, Ashwood $\mathrm{P}$, et al. Autism-specific maternal autoantibodies recognize critical proteins in developing brain. Transl Psychiatry (2013) 3:e277. doi: 10.1038/tp.2013.50

81. Nordahl CW, Braunschweig D, Iosif A-M, Lee A, Rogers S, Ashwood P, et al. Van de Water Maternal autoantibodies are associated with abnormal brain enlargement in a subgroup of children with autism spectrum disorder. Brain Behav And Immun. (2013) 30:61-5. doi: 10.1016/j.bbi.2013.01.084

82. Pieper R, Kroger S, Richter JF, Wang J, Martin L, Bindelle J, et al. Fermentable fiber ameliorates fermentable protein-induced changes in microbial ecology, but not the mucosal response, in the colon of piglets. J Nutr. (2012) 142:6617. doi: $10.3945 /$ jn. 111.156190

83. Mu C, Yang Y, Luo Z, Guan L, Zhu W. The colonic microbiome and epithelial transcriptome are altered in rats fed a high-protein diet compared with a normal-protein diet. J Nutr. (2016) 146:474-83. doi: 10.3945/jn.115.223990

84. Duncan SH, Belenguer A, Holtrop G, Johnstone AM, Flint HJ, Lobley GE. Reduced dietary intake of carbohydrates by obese subjects results in decreased concentrations of butyrate and butyrateproducing bacteria in feces. Appl Environ Microbiol. (2007) 73:1073-8. doi: 10.1128/AEM.02340-06

85. Liu X, Blouin JM, Santacruz A, Lan A, Andriamihaja M, Wilkanowicz S, et al. High-protein diet modifies colonic microbiota and luminal environment but not colonocyte metabolism in the rat model: the increased luminal bulk connection. Am J Physiol Gastrointest Liver Physiol. (2014) 307:G459-70. doi: 10.1152/ajpgi.00400.2013

86. Geypens B, Claus D, Evenepoel P, Hiele M, Maes B, Peeters M, et al. Influence of dietary protein supplements on the formation of bacterial metabolites in the colon. Gut (1997) 41:70-6. doi: 10.1136/gut.41.1.70

87. Toden S, Bird AR, Topping DL, Conlon MA. (2007b). High red meat diets induce greater numbers of colonic DNA double-strand breaks than white meat in rats: attenuation by high-amylose maize starch. Carcinogenesis 28:2355-62. doi: 10.1093/carcin/bgm216

88. An C, Kuda T, Yazaki T, Takahashi H, Kimura B. Caecal fermentation, putrefaction and microbiotas in rats fed milk casein, soy protein or fish meal. Appl Microbiol Biotechnol. (2014) 98:2779-87. doi: 10.1007/s00253-013-5271-5

89. Rowan FE, Docherty NG, Coffey JC, O'Connell PR. Sulphate-reducing bacteria and hydrogen sulphide in the aetiology of ulcerative colitis. Br J Surg. (2009) 96:151-8. doi: 10.1002/bjs.6454

90. Khalil NA, Walton GE, Gibson GR, Tuohy KM, Andrews SC. In vitro batch cultures of gut microbiota from healthy and ulcerative colitis (UC) subjects suggest that sulphate-reducing bacteria levels are raised in UC and by a protein-rich diet. Int J Food Sci Nutr. (2014) 65:79-88. doi: 10.3109/09637486.2013.825700

91. Toden S, Bird AR, Topping DL, Conlon MA. (2007a). Differential effects of dietary whey, casein and soya on colonic DNA damage and large bowel SCFA in rats fed diets low and high in resistant starch. Br J Nutr. 97:535-43. doi: $10.1017 /$ S0007114507336817

92. Hughes R, Kurth MJ, McGilligan V, McGlynn H, Rowland I. Effect of colonic bacterial metabolites on Caco-2 cell paracellular permeability in vitro. Nutr Cancer (2008) 60:259-66. doi: 10.1080/01635580701649644

93. McCall IC, Betanzos A, Weber DA, Nava P, Miller GW, Parkos CA. Effects of phenol on barrier function of a human intestinal epithelial cell line correlate with altered tight junction protein localization. Toxicol Appl Pharmacol. (2009) 241:61-70. doi: 10.1016/j.taap.2009.08.002

94. Andriamihaja M, Davila AM, Eklou-Lawson M, Petit N, Delpal S, Allek F, et al. Colon luminal content and epithelial cell morphology are markedly 
modified in rats fed with a high-protein diet. Am J Physiol Gastrointest Liver Physiol. (2010) 299:G1030-37. doi: 10.1152/ajpgi.00149.2010

95. Medani M, Collins D, Docherty NG, Baird AW, O'Connell PR, Winter DC. Emerging role of hydrogen sulfide in colonic physiology and pathophysiology. Inflamm Bowel Dis. (2011) 17:1620-25. doi: 10.1002/ibd.21528

96. Andriamihaja M, Lan A, Beaumont M, Audebert M, Wong X, Yamada K, et al. The deleterious metabolic and genotoxic effects of the bacterial metabolite p-cresol on colonic epithelial cells. Free Radic Biol Med. (2015) 85:219-27. doi: 10.1016/j.freeradbiomed.2015.04.004

97. Macfarlane GT, Cummings JH, Allison C. Protein degradation by human intestinal bacteria. J Gen Microbiol. (1986) 132:1647-656. doi: 10.1099/00221287-132-6-1647

98. Davila AM, Blachier F, Gotteland M, Andriamihaja M, Benetti PH, Sanz Y, et al. Re-print of intestinal luminal nitrogen metabolism: role of the gut microbiota and consequences for the host. Pharmacol Res. (2013) 69:114-26. doi: 10.1016/j.phrs.2013.01.003

99. Richardson AJ, McKain N, Wallace RJ. Ammonia production by human faecal bacteria, and the enumeration, isolation and characterization of bacteria capable of growth on peptides and amino acids. BMC Microbiol. (2013) 13:6. doi: 10.1186/1471-2180-13-6

100. Compare D, Rocco A, Sanduzzi Zamparelli M, Nardone G. The gut bacteria-driven obesity development. Dig Dis. (2016) 34:221-9. doi: $10.1159 / 000443356$

101. Blachier F, Mariotti F, Huneau JF, Tome D. Effects of amino acid-derived luminal metabolites on the colonic epithelium and physiopathological consequences. Amino Acids (2007) 33:547-62. doi: 10.1007/s00726-006-0477-9

102. Windey K, De Preter V, Verbeke K. Relevance of protein fermentation to gut health. Mol Nutr Food Res. (2012) 56:184-96. doi: 10.1002/mnfr.201100542

103. Pedersen G, Brynskov J, Saermark T. Phenol toxicity and conjugation in human colonic epithelial cells. Scand J Gastroenterol. (2002) 37:74-9. doi: 10.1080/003655202753387392

104. Attene-Ramos MS, Wagner ED, Plewa MJ, Gaskins HR. Evidence that hydrogen sulfide is a genotoxic agent. Mol Cancer Res. (2006) 4:9-14. doi: 10.1158/1541-7786.MCR-05-0126

105. Roediger WE, Duncan A, Kapaniris O, Millard S. Sulphide impairment of substrate oxidation in rat colonocytes: a biochemical basis for ulcerative colitis? Clin Sci. (1993) 85:623-7. doi: 10.1042/cs0850623

106. Leschelle $X$, Goubern $M$, Andriamihaja $M$, Blottière HM, Couplan $\mathrm{E}$, Gonzalez-Barroso $\mathrm{M}$, et al. Adaptative metabolic response of human colonic epithelial cells to the adverse effects of the luminal compound sulfide. Biochim Biophys Acta Gen Sub. (2005) 1725:201-12. doi: 10.1016/j.bbagen.2005.06.002

107. Macfabe DF. Short-chain fatty acid fermentation products of the gut microbiome: implications in autism spectrum disorders. Microb Ecol Health Dis. (2012) 2012:23. doi: 10.3402/mehd.v23i0.19260

108. Gabriele S, Sacco R, Cerullo S, Neri C, Urbani A, Tripi G, et al. Urinary p-cresol is elevated in young French children with autism spectrum disorder: a replication study. Biomarkers(2014) 19:463-70. doi: 10.3109/1354750X.2014.936911

109. de Baulny HO, Benoist JF, Rigal O, Touati G, Rabier D, Saudubray JM. Methylmalonic and propionic acidaemias: management and outcome. $J$ Inherit Metab Dis. (2005) 28:415-23. doi: 10.1007/s10545-005-7056-1

110. Schreiber J, Chapman KA, Summar ML, Ah Mew N, Sutton VR, MacLeod E, et al. Neurologic considerations in propionic acidemia. Mol Genet Metab. (2012) 105:10-5. doi: 10.1016/j.ymgme.2011.10.003

111. MacFabe DF, Cain DP, Rodriguez-Capote K, Franklin AE, Hoffman JE, Boon F, et al. Neurobiological effects of intraventricular propionic acid in rats: possible role of short chain fatty acids on the pathogenesis and characteristics of autism spectrum disorders. Behav Brain Res. (2007) 176:149-69. doi: 10.1016/j.bbr.2006.07.025

112. Shultz SR, MacFabe DF, Ossenkopp P, Scratch S, Whelan J, Cain DP, et al. Intracerebroventricular injection of propionic acid, an enteric bacterial metabolic end-product, impairs social behavior in the rat: implications for an animal model of autism. Neuropharmacology (2008) 54:901-11. doi: 10.1016/j.neuropharm.2008.01.013
113. Shultz SR, Aziz NA, Yang L, Sun M, MacFabe DF, O’Brien TJ. Intracerebroventricular injection of propionic acid, an enteric metabolite implicated in autism, induces social abnormalities that do not differ between seizure-prone (FAST) and seizure-resistant (SLOW) rats. Behav Brain Res. (2015) 278:542-8. doi: 10.1016/j.bbr.2014.10.050

114. Thomas RH, Foley KA, Mepham JR, Tichenoff LJ, Possmayer F, MacFabe DF. Altered brain phospholipid and acylcarnitine profiles in propionic acid infused rodents: further development of a potential model of autism spectrum disorders. J Neurochem. (2010) 113:515-529. doi: 10.1111/j.1471-4159.2010.06614.x

115. MacFabe DF, Cain NE, Boon F, K.-,Ossenkopp P, Cain DP. Effects of the enteric bacterial metabolic product propionic acid on object-directed behavior, social behavior, cognition, and neuroinflammation in adolescent rats: relevance to autism spectrum disorder. Behav Brain Res. (2011) 217:47-54. doi: 10.1016/j.bbr.2010.1 0.005

116. Ossenkopp KP, Foley KA, Gibson J, Fudge MA, Kavaliers M, Cain DP, et al. Systemic treatment with the enteric bacterial fermentation product, propionic acid, produces both conditioned taste avoidance and conditioned place avoidance in rats. Behav Brain Res. (2012) 227:134-41. doi: 10.1016/j.bbr.2011.10.045

117. Khalil SR, Abd-Elhakim YM, Selim ME, Al-Ayadhi LY. Apitoxin protects rat pups brain from propionic acid-induced oxidative stress: The expression pattern of Bcl- (2015) 2 and Caspase-3 apoptotic genes. Neurotoxicology 49:121-31. doi: 10.1016/j.neuro.2015.05.011

118. Foley KA, MacFabe DF, Kavaliers M, Ossenkopp KP. Sexually dimorphic effects of prenatal exposure to lipopolysaccharide, and prenatal and postnatal exposure to propionic acid, on acoustic startle response and prepulse inhibition in adolescent rats: relevance to autism spectrum disorders. Behav Brain Res. (2015) 278:244-56. doi: 10.1016/j.bbr.2014.09.032

119. El-Ansary A, Shaker GH, El-Gezeery AR, Al-Ayadhi L. The neurotoxic effect of clindamycin - induced gut bacterial imbalance and orally administered propionic acid on DNA damage assessed by the comet assay: protective potency of carnosine and carnitine. Gut Pathog. (2013) 5:9. doi: 10.1186/1757-4749-5-9

120. MacFabe DF. Enteric short-chain fatty acids: microbial messengers of metabolism, mitochondria, and mind: implications in autism spectrum disorders. Microb Ecol Health Dis. (2015) 26:28177. doi: $10.3402 /$ mehd.v26.28177

121. Burrus CJ. A biochemical rationale for the interaction between gastrointestinal yeast and autism. Med Hypotheses (2012) 79:784-5. doi: 10.1016/j.mehy.2012.08.029

122. Ishiwari K, Mingote S, Correa M, Trevitt JT, Carlson BB, Salamone JD. The GABA uptake inhibitor beta-alanine reduces pilocarpine-induced tremor and increases extracellular GABA in substantia nigra pars reticulata as measured by microdialysis. J Neurosci Methods (2004) 140:39-46. doi: 10.1016/j.jneumeth.2004.03.030

123. Komura J, Tamai I, Senmaru M, Terasaki T, Sai Y, Tsuji A. Brain-to-blood active transport of beta-alanine across the blood-brain barrier. FEBS Lett. (1997) 400:131-5. doi: 10.1016/S0014-5793(96)01366-X

124. Gorker I, Tuzun U. Autistic-like findings associated with a urea cycle disorder in a 4-year-old girl. J Psychiatry Neurosci. (2005) 30:133-135.

125. Sedel F, Baumann N, Turpin JC, Lyon-Caen O, Saudubray JM, Cohen D. Psychiatric manifestations revealing inborn errors of metabolism in adolescents and adults. J Inherit Metab Dis. (2007) 30:631-41. doi: 10.1007/s10545-007-0661-4

126. Clayton TA. Metabolic differences underlying two distinct rat urinary phenotypes, a suggested role for gut microbial metabolism of phenylalanine and a possible connection to autism. FEBS Lett. (2012) 586:956-61. doi: 10.1016/j.febslet.2012.01.049

127. Hsiao EY, McBride SW, Hsien S, Sharon G, Hyde ER, McCue T, et al. Microbiota modulate behavioral and physiological abnormalities associated with neurodevelopmental disorders. Cell (2013) 155:1451-63. doi: 10.1016/j.cell.2013.11.024

128. Becker PM, Yu P. What makes protein indigestible from tissue-related, cellular, and molecular aspects? Mol Nutr Food Res (2013) 57:1695-1707. doi: $10.1002 / \mathrm{mnfr} .201200592$ 
129. Gardner ML. Intestinal assimilation of intact peptides and proteins from the diet-a neglected field? Biol Rev Camb Philos Soc. (1984) 59:289-331. doi: 10.1111/j.1469-185X.1984.tb00708.x

130. Beynon RJ, Bond JS. Catabolism of intracellular protein: molecular aspects. Am J Physiol. (1986) 251(2 Pt 1):C141-152. doi: 10.1152/ajpcell.1986.251.2.C141

131. Mortimore GE, Poso AR. Intracellular protein catabolism and its control during nutrient deprivation and supply. Annu Rev Nutr. (1987) 7:539-64. doi: 10.1146/annurev.nu.07.070187.002543

132. Sareneva T, Pirhonen J, Cantell K, Julkunen I. N-glycosylation of human interferon-gamma: glycans at Asn-25 are critical for protease resistance. Biochem J. (1995) 308 (Pt 1):9-14. doi: 10.1042/bj3080009

133. Yu YQ, Fournier J, Gilar M, Gebler JC. Identification of N-linked glycosylation sites using glycoprotein digestion with pronase prior to MALDI tandem time-of-flight mass spectrometry. Anal Chem. (2007) 79:1731-8. doi: 10.1021/ac0616052

134. Boutrou R, Coirre E, Jardin J, Leonil J. Phosphorylation and coordination bond of mineral inhibit the hydrolysis of the beta-casein (1-25) peptide by intestinal brush-border membrane enzymes. J Agric Food Chem. (2010) 58:7955-61. doi: 10.1021/jf100568r

135. Schlemmer U, Frolich W, Prieto RM, Grases F. Phytate in foods and significance for humans: food sources, intake, processing, bioavailability, protective role and analysis. Mol Nutr Food Res. (2009) 53(Suppl. 2):S330-75. doi: 10.1002/mnfr.200900099

136. Serrano J, Puupponen-Pimiä R, Dauer A, Aura AM, Saura-Calixto F. Tannins: current knowledge of food sources, intake, bioavailability and biological effects. Mol Nutr Food Res. (2009) 53(S2):S310-29. doi: 10.1002/mnfr.200900039

137. Wu YV, Sessa DJ. Conformation of Bowman-Birk Inhibitor. J Agric Food Chem. (1994) 42:2136-8. doi: 10.1021/jf00046a012

138. Roychaudhuri R, Sarath G, Zeece M, Markwell J. Stability of the allergenic soybean Kunitz trypsin inhibitor. Biochim Biophys Acta (2004) 1699:207-12. doi: 10.1016/S1570-9639(04)00065-2

139. Kumar R, Singh M. Tannins: their adverse role in ruminant nutrition. J Agric Food Chem (1984) 32:447-53. doi: 10.1021/jf00123a006

140. Chung KT, Wong TY, Wei CI, Huang YW, Lin Y. Tannins and human health: a review. Crit Rev Food Sci Nutr. (1998) 38:421-64. doi: 10.1080/10408699891274273

141. Hagerman AE, Robbins CT, Yohan W, Wilson TC, McArthur C. Tannin chemistry in relation to digestion. J Range Manage. (1992) 45:57-62. doi: $10.2307 / 4002526$

142. Smith AH, Zoetendal E, Mackie RI. Bacterial mechanisms to overcome inhibitory effects of dietary tannins. Microb Ecol. (2005) 50:197-205. doi: 10.1007/s00248-004-0180-x

143. Butler LG, Rogler JC. Biochemical mechanisms of the antinutritional effects of tannins. Phenolic Comp Food Effects Health I Am Chem Soc. (1992) 506:298-304. doi: 10.1021/bk-1992-0506.ch023

144. Knuckles BE, Kuzmicky DD, Betschart AA. Effect of phytate and partially hydrolyzed phytate on in vitro protein digestibility. J Food Sci. (1985) 50:1080-82. doi: 10.1111/j.1365-2621.1985.tb13016.x

145. Dallas DC, Sanctuary MR, Qu Y, Khajavi SH, Van Zandt AE, Dyandra M, et al. Personalizing protein nourishment. Crit Rev Food Sci Nutr. (2015) 57:3313-31. doi: 10.1080/10408398.2015.1117412

146. Hamaker BR, Kirleis AW, Mertz ET, Axtell JD. Effect of cooking on the protein profiles and in vitro digestibility of sorghum and maize. J Agric Food Chem. (1986) 34:647-9. doi: 10.1021/jf00070a014

147. Emmambux MN, Taylor JR. Properties of heat-treated sorghum and maize meal and their prolamin proteins. J Agric Food Chem. (2009) 57:1045-50. doi: $10.1021 /$ jf802672e

148. Lonnerdal B. Infant formula and infant nutrition: bioactive proteins of human milk and implications for composition of infant formulas. Am J Clin Nutr. (2014) 99:712s-7. doi: 10.3945/ajcn.113.0 71993

149. Rudloff S, Lonnerdal B. Solubility and digestibility of milk proteins in infant formulas exposed to different heat treatments. J Pediatr Gastroenterol Nutr. (1992) 15:25-33. doi: 10.1097/00005176-19920700000005
150. Lindberg T, Engberg S, Sjoberg LB, Lonnerdal B. In vitro digestion of proteins in human milk fortifiers and in preterm formula. J Pediatr Gastroenterol Nutr. (1998) 27:30-6. doi: 10.1097/00005176-199807000-00006

151. Almaas H, Holm H, Langsrud T, Flengsrud R, Vegarud GE. In vitro studies of the digestion of caprine whey proteins by human gastric and duodenal juice and the effects on selected microorganisms. Br J Nutr. (2006) 96:562-9. doi: 10.1079/BJN20061739

152. Dupont D, Mandalari G, Molle D, Jardin J, Rolet-Repecaud O, Duboz G, et al. Food processing increases casein resistance to simulated infant digestion. Mol Nutr Food Res. (2010) 54:1677-89. doi: 10.1002/mnfr.200900582

153. Wada Y, Lonnerdal B. Effects of different industrial heating processes of milk on site-specific protein modifications and their relationship to in vitro and in vivo digestibility. J Agric Food Chem. (2014) 62:4175-85. doi: $10.1021 /$ jf501617s

154. Lindberg T, Engberg S, Jakobsson I, Lonnerdal B. Digestion of proteins in human milk, human milk fortifier, and preterm formula in infant rhesus monkeys. J Pediatr Gastroenterol Nutr. (1997) 24:537-43. doi: 10.1097/00005176-199705000-00009

155. Lesser LI, Mazza MC, Lucan SC. Nutrition myths and healthy dietary advice in clinical practice. Am Fam Phys. (2015) 91:634-638.

156. Sauniere JF, Sarles H, Attia Y, Lombardo A, Yoman TN, Laugier R, et al. Exocrine pancreatic function of children from the ivory coast compared to french children. effect of kwashiorkor. Dig Dis Sci. (1986) 31:481-6. doi: 10.1007/BF01320311

157. Carroccio A, Iacono G, Montalto G, Cavataio F, Di Marco C, Balsamo V, et al. Exocrine pancreatic function in children with coeliac disease before and after a gluten free diet. Gut (1991) 32:796-9. doi: 10.1136/gut.32.7.796

158. Evans KE, Leeds JS, Morley S, Sanders DS. Pancreatic insufficiency in adult celiac disease: do patients require long-term enzyme supplementation? Dig Dis Sci. (2010) 55:2999-3004. doi: 10.1007/s10620-010-1261-y

159. Nousia-Arvanitakis S, Karagiozoglou-Lamboudes T, Aggouridaki C, Malaka-Lambrellis E, Galli-Tsinopoulou A, Xefteri M. Influence of jejunal morphology changes on exocrine pancreatic function in celiac disease. J Pediatr Gastroenterol Nutr. (1999) 29:81-5. doi: 10.1097/00005176-199907000-00019

160. Carroccio A, Iacono G, Montalto G, Cavataio F, Lorello D, Soresi M, et al. Pancreatic insufficiency in celiac disease is not dependent on nutritional status. Dig Dis Sci. (1994) 39:2235-42. doi: 10.1007/BF02090377

161. Leeds JS, Hopper AD, Sidhu R, Simmonette A, Azadbakht N, Hoggard $\mathrm{N}$, et al. Some patients with irritable bowel syndrome may have exocrine pancreatic insufficiency. Clin Gastroenterol Hepatol. (2010) 8:4338. doi: 10.1016/j.cgh.2009.09.032

162. Maconi G, Dominici R, Molteni M, Ardizzone S, Bosani M, Ferrara E, et al. Prevalence of pancreatic insufficiency in inflammatory bowel diseases. Assessment by fecal elastase-1. Dig Dis Sci. (2008) 53:262-70. doi: 10.1007/s10620-007-9852-y

163. Walkowiak J, Herzig KH. Fecal elastase-1 is decreased in villous atrophy regardless of the underlying disease. Eur J Clin Invest. (2001) 31:425-30. doi: 10.1046/j.1365-2362.2001.00822.x

164. Lebenthal E, Antonowicz I, Shwachman H. The interrelationship of enterokinase and trypsin activities in intractable diarrhea of infancy, celiac disease, and intravenous alimentation. Pediatrics (1975) 56:585-91.

165. Nissler K, Von Katte I, Huebner A, Henker J. Pancreatic elastase 1 in feces of preterm and term infants. J Pediatr Gastroenterol Nutr. (2001) 33:28-31. doi: 10.1097/00005176-200107000-00005

166. Kolacek S, Puntis JW, Lloyd DR, Brown GA, Booth IW. Ontogeny of pancreatic exocrine function. Arch Dis Child. (1990) 65:178-81. doi: 10.1136/adc.65.2.178

167. Salvatore S, Finazzi S, Barassi A, Verzelletti M, Tosi A, Melzi d'Eril GV, et al. Low fecal elastase: potentially related to transient small bowel damage resulting from enteric pathogens. J Pediatr Gastroenterol Nutr. (2003) 36:392-6. doi: 10.1097/00005176-200303000-00018

168. Larger E, Philippe MF, Barbot-Trystram L, Radu A, Rotariu M, Nobecourt E, et al. Pancreatic exocrine function in patients with diabetes. Diabet Med. (2012) 29:1047-54. doi: 10.1111/j.1464-5491.2012.03597.x

169. Herzig KH, Purhonen AK, Rasanen KM, Idziak J, Juvonen P, Phillps R, et al. Fecal pancreatic elastase-1 levels in older individuals without known 
gastrointestinal diseases or diabetes mellitus. BMC Geriatr. (2011) 11:4. doi: 10.1186/1471-2318-11-4

170. Pezzilli R, Barassi A, Morselli-Labate AM, Fantini L, Tomassetti P, Campana D, et al. Fecal calprotectin and elastase 1 determinations in patients with pancreatic diseases: a possible link between pancreatic insufficiency and intestinal inflammation. J Gastroenterol. (2007) 42:754-60. doi: 10.1007/s00535-007-2086-0

171. Osvaldo Danus V, Ana Maria Urbina QF, Valenzuela I, Giorgio Solimano C. The effect of refeeding on pancreatic exocrine function in marasmic infants. J Pediatr. (1970) 77:334-7. doi: 10.1016/S0022-3476(70) 80347-X

172. Sauniere JF, Sarles H. Exocrine pancreatic function and protein-calorie malnutrition in Dakar and Abidjan (West Africa): silent pancreatic insufficiency. Am J Clin Nutr. (1988) 48:1233-8. doi: 10.1093/ajcn/48. 5.1233

173. Luth S, Teyssen S, Forssmann K, Kolbel C, Krummenauer F, Singer MV. Fecal elastase-1 determination: 'gold standard' of indirect pancreatic function tests? Scand J Gastroenterol. (2001) 36:1092-99. doi: 10.1080/003655201750422729

174. Wali PD, Loveridge-Lenza B, He Z, Horvath K. Comparison of fecal elastase1 and pancreatic function testing in children. J Pediatr Gastroenterol Nutr. (2012) 54:277-80. doi: 10.1097/MPG.0b013e31820b0227

175. Fond G, Loundou A, Hamdani N, Boukouaci W, Dargel A, Oliveira J, et al. Anxiety and depression comorbidities in irritable bowel syndrome (IBS): a systematic review and meta-analysis. Eur Archiv Psychiatry Clin Neurosci. (2014) 264:651-60. doi: 10.1007/s00406-014-0502-z

176. Fetissov SO, Dechelotte P. The new link between gut-brain axis and neuropsychiatric disorders. Curr Opin Clin Nutr Metab Care (2011) 14:47782. doi: 10.1097/MCO.0b013e32834936e7

177. Sandler RH, Finegold SM, Bolte ER, Buchanan CP, Maxwell AP, Vaisanen ML, et al. Short-term benefit from oral vancomycin treatment of regressive-onset autism. J Child Neurol. (2000) 15:429-35. doi: $10.1177 / 088307380001500701$

178. Whiteley P. Nutritional management of (some) autism: a case for gluten- and casein-free diets? Proc Nutr Soc. (2015) 74:202-7. doi: 10.1017/S0029665114001475

179. Knivsberg AM, Reichelt KL, Nødland M, Høien T. Autistic syndromes and diet: a follow-up study. J Curr Stud. (1995) 39:223-36. doi: $10.1080 / 0031383950390304$

180. Knivsberg A, Reichelt K, Høien T, Nødland M. A randomised, controlled study of dietary intervention in autistic syndromes. Nutr Neurosci. (2002) 5:251-61. doi: 10.1080/10284150290028945

181. Knivsberg, AM, Reichelt KL, Høien T, Nødland M. Effect of a dietary intervention on autistic behavior. Focus Autism Other Dev Disab. (2003) 18:248-57. doi: 10.1177/10883576030180040601

182. Whiteley P, Haracopos D, Knivsberg AM, Reichelt KL, Parlar S, Jacobsen J, et al. The ScanBrit randomised, controlled, single-blind study of a gluten- and casein-free dietary intervention for children with autism spectrum disorders. Nutr Neurosci. (2010) 13:87-100. doi: 10.1179/147683010X12611460763922

183. Pennesi CM, Klein LC. Effectiveness of the gluten-free, casein-free diet for children diagnosed with autism spectrum disorder: based on parental report. Nutr Neurosci. (2012) 15:85-91. doi: 10.1179/1476830512Y.0000000003

184. Ermer J, Dunn W. The sensory profile: a discriminant analysis of children with and without disabilities. Am J Occup Ther. (1998) 52:283-90. doi: 10.5014/ajot.52.4.283

185. Cermak SA, Curtin C, Bandini LG. Food selectivity and sensory sensitivity in children with autism spectrum disorders. J Am Die Assoc. (2010) 110:238-46. doi: 10.1016/j.jada.2009.10.032

186. Attlee A, Kassem H, Hashim M, Obaid RS. Physical status and feeding behavior of children with autism. Indian J Pediatr. (2015) 82:682-7. doi: 10.1007/s12098-015-1696-4

187. Watling RL, Deitz J, White O. Comparison of sensory profile scores of young children with and without autism spectrum disorders. Am J Occup Ther. (2001) 55:416-23. doi: 10.5014/ajot.55.4.416

188. Bennetto L, Kuschner ES, Hyman SL. Olfaction and taste processing in autism. Biol Psychiatry (2007) 62:1015-21. doi: $10.1016 /$ j.biopsych.2007.04.019
189. Helt MS, Fein DA. Facial feedback and social input: effects on laughter and enjoyment in children with autism spectrum disorders. J Autism Develop Disord. (2016) 46:83-94. doi: 10.1007/s10803-015-2545-z

190. Jeltema M, Beckley J, Vahalik J. Model for understanding consumer textural food choice. Food Sci Nutr. (2015) 3:202-12. doi: 10.1002/fsn3.205

191. Hamer HM, De Preter V, Windey K, Verbeke K. Functional analysis of colonic bacterial metabolism: relevant to health? Am J Physiol Gastrointest Liver Physiol. (2012) 302:G1-9. doi: 10.1152/ajpgi.00048.2011

192. Arroyo C, Eslami S, Brunton NP, Arimi JM, Noci F, Lyng JG. An assessment of the impact of pulsed electric fields processing factors on oxidation, color, texture, and sensory attributes of turkey breast meat. Poul Sci. (2015) 94:1088-95. doi: 10.3382/ps/pev097

193. Barbut S, Youssef M. Effect of gradual heating and Fat/Oil type on fat stability, texture, color, and microstructure of meat batters. J Food Sci. (2016) 81:C2199-205. doi: 10.1111/1750-3841.13420

194. Guerrero L, Gou P, Arnau J. The influence of meat $\mathrm{pH}$ on mechanical and sensory textural properties of dry-cured ham. Meat Sci. (1999) 52:267-73. doi: 10.1016/S0309-1740(98)00175-2

195. Chandrapala J, Zisu B. Novel trends in engineered milk products. J Dairy Res. (2016) 83:268-80. doi: 10.1017/S0022029916000479

196. Bicer AH, Alsaffar AA. Body mass index, dietary intake and feeding problems of Turkish children with autism spectrum disorder (ASD). Res Dev Disab. (2013) 34:3978-87. doi: 10.1016/j.ridd.2013.08.024

197. Schreck KA, Williams K. Food preferences and factors influencing food selectivity for children with autism spectrum disorders. Res Dev Disab. (2006) 27:353-63. doi: 10.1016/j.ridd.2005.03.005

198. Schreck KA, Williams K, Smith AF. A comparison of eating behaviors between children with and without autism. J Autism Dev Disord. (2004) 34:433-8. doi: 10.1023/B:JADD.0000037419.78531.86

199. Holzer P, Farzi A. Neuropeptides and the microbiota-gut-brain axis. Adv Exp Med Biol. (2014) 817:195-219. doi: 10.1007/978-1-4939-0897-4_9

200. Schlundt J (2001). Health and Nutritional Properties of Probiotics in Food Including Powder Milk With Live Lactic Acid Bacteria. Cordoba: WHO/FAO, $1-34$.

201. Azais-Braesco V, Bresson JL, Guarner F, Corthier G. Not all lactic acid bacteria are probiotics, ...but some are. Br J Nutr. (2010) 103:1079-81. doi: $10.1017 /$ S0007114510000723

202. Golnik AE, Ireland M. Complementary alternative medicine for children with autism: a physician survey. J Autism Dev Disord. (2009) 39:996-1005. doi: 10.1007/s10803-009-0714-7

203. Kaluzna-Czaplinska J, Blaszczyk S. The level of arabinitol in autistic children after probiotic therapy. Nutrition (2012) 28:124-6. doi: 10.1016/j.nut.2011.08.002

204. Russo AJ. Decreased plasma myeloperoxidase associated with probiotic therapy in autistic children. Clin Med Insights Pediatr. (2015) 9:13-17. doi: 10.4137/CMPed.S17901

205. Mari-Bauset S, Llopis-Gonzalez A, Zazpe I, Mari-Sanchis A, Suarez-Varela MM. Nutritional impact of a gluten-free casein-free diet in children with autism spectrum disorder. J Autism Dev Disord. (2016) 46:673-84. doi: 10.1007/s10803-015-2582-7

206. Brudnak MA, Rimland B, Kerry RE, Dailey M, Taylor R, Stayton B, et al. Enzyme-based therapy for autism spectrum disorders - is it worth another look? Med Hypotheses (2002) 58:422-8. doi: 10.1054/mehy.2001.1513

207. Saad K, Eltayeb AA, Mohamad IL, Al-Atram AA, Elserogy Y, Bjorklund $\mathrm{G}$, et al. A randomized, placebo-controlled trial of digestive enzymes in children with autism spectrum disorders. Clin Psychopharmacol Neurosci. (2015) 13:188-93. doi: 10.9758/cpn.2015.13.2.188

208. Munasinghe SA, Oliff C, Finn J, Wray JA. Digestive enzyme supplementation for autism spectrum disorders: a double-blind randomized controlled trial. $J$ Autism Dev Disord. (2010) 40:1131-8. doi: 10.1007/s10803-010-0974-2

209. Albalat A, Mischak H, Mullen W. Clinical application of urinary proteomics/peptidomics. Exp Rev Proteomics (2011) 8:615-29. doi: 10.1586/epr.11.46

210. Ray S, Reddy PJ, Jain R, Gollapalli K, Moiyadi A, Srivastava S. Proteomic technologies for the identification of disease biomarkers in serum: advances and challenges ahead. Proteomics (2011) 11:2139-61. doi: 10.1002/pmic. 201000460 
211. Dallas DC, Guerrero A, Khaldi N, Borghese R, Bhandari A, Underwood MA, et al. A peptidomic analysis of human milk digestion in the infant stomach reveals protein-specific degradation patterns. (2014) J Nutr. 144:815-20. doi: 10.3945/jn.113.185793

212. Dallas DC, Guerrero A, Parker EA, Robinson RC, Gan J, German JB, et al. Current peptidomics: applications, purification, identification, quantification, and functional analysis. Proteomics (2015) 15:1026-38. doi: 10.1002/pmic.2014 00310

213. Dallas DC, Guerrero A, Khaldi N, Castillo PA, Martin WF, Smilowitz JT, et al. Extensive in vivo human milk peptidomics reveals specific proteolysis yielding protective antimicrobial peptides. J Proteo Res. (2013) 12:2295-304. doi: 10.1021/pr40 $0212 \mathrm{z}$
Conflict of Interest Statement: JB German is a cofounder of Evolve Biosystems a commercial entity providing products for breast fed infants.

The other authors declare that the research was conducted in the absence of any commercial or financial relationships that could be construed as a potential conflict of interest.

Copyright (c) 2018 Sanctuary, Kain, Angkustsiri and German. This is an openaccess article distributed under the terms of the Creative Commons Attribution License (CC BY). The use, distribution or reproduction in other forums is permitted, provided the original author(s) and the copyright owner are credited and that the original publication in this journal is cited, in accordance with accepted academic practice. No use, distribution or reproduction is permitted which does not comply with these terms. 